$2-1-2004$

\title{
Can Treasury Overrule the Supreme Court?
}

\author{
Gregg D. Polsky \\ University of Georgia School of Law, gregg.polsky@uga.edu
}

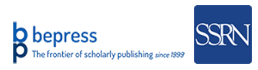

\section{Repository Citation}

Gregg D. Polsky, Can Treasury Overrule the Supreme Court? , 84 B.U. L. Rev. 185 (2004),

Available at: https://digitalcommons.law.uga.edu/fac_artchop/1104

This Article is brought to you for free and open access by the Faculty Scholarship at Digital Commons @ University of Georgia School of Law. It has been accepted for inclusion in Scholarly Works by an authorized administrator of Digital Commons @ University of Georgia School of Law. Please share how you have benefited from this access For more information, please contact tstriepe@uga.edu. 


\title{
CAN TREASURY OVERRULE THE SUPREME COURT?
}

\author{
GREGG D. POLSKY*
}

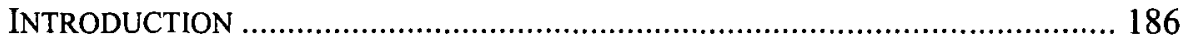

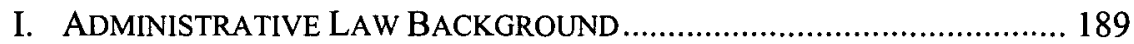

A. Pre-Chevron Law ..................................................................... 189

B. Chevron's Impact-Victory for the Deferential Model? .............. 191

C. United States v. Mead: The Return of the Independent Judgment Model

D. The Conflict Between Chevron and Stare Decisis ...................... 199

E. Chevron's Applicability to Tax Regulations ................................. 207

1. Pre-Chevron Law .............................................................. 207

2. Does Chevron Apply to Tax Law?...................................... 209

3. Are General Authority Regulations Mead-Qualified?........... 210

II. THE HISTORICAL DEFINITION OF "ASSOCIATION": FROM MORRISEY TO CHECK-THE-BOX ................................................................. 212

A. Morrissey v. Commissioner........................................................ 213

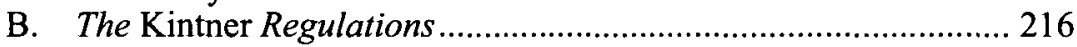

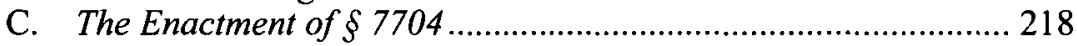

D. The Proliferation of the Limited Liability Company .................... 220

III. ANALYSIS OF THE VALIDITY OF THE CHECK-THE-BOX

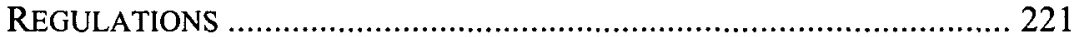

A. The Validity of the Regulations under a Chevron Analysis ......... 222

1. Arguments Made Against Validity ...................................... 222

2. Arguments Made in Favor of Validity ................................ 223

B. Appropriate Analysis of the Validity of the Check-the-Box

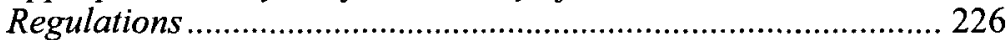

1. Application of the Incorporation Rule................................ 226

2. Possible Counter-Arguments.............................................. 227

a. Consistency with Morrissey ............................................. 227

b. Super-Chevron Powers in Entity. Classification? ............. 228

c. Alternatives to the Incorporation Rule ............................ 229

i. Re-Examination Approach ..................................... 229

* Associate Professor, University of Minnesota Law School. I wish to thank Guy-Uriel Charles, Shayna Sigman, Jim Chen, Dan Farber, Brant Hellwig, Ellen Aprill, Gregory Germain, Bruce Shnider, Victor Fleischer, Jeff Kahn, David Richardson, Martin McMahon, Jr., Michael Paulsen, Dan Gifford, Rachel Polsky, Mary Louise Fellows, Leandra Lederman, Nathan Honson, and Michael Kirsch for their comments on an earlier draft. I also thank George Mundstock and Mitchell Gans for helpful discussions on the topic. Eliot Wren and Dan Grimsrud provided valuable research assistance. Finally, I wish to thank my wife, Rina Lyubkin, for her immeasurable help and support. Of course, any errors or omissions are solely my responsibility. 
ii. Provisional Precedent Approach ............................ 231

d. Overruling Morrissey .................................................... 232

e. Ratification of the Regulations by Acquiescence............. 236

IV. How COULD TREASURY HAVE ISSUED INVALID REGULATIONS? ....... 238

A. Negligence and the Sociology of the Tax Community .................. 238

B. Intent and the Effect of Taxpayer Standing Doctrine ................... 238

1. The Case of the Foreign Entity's Failure to Elect ................. 239

2. The Case of the Partner Trying to Avoid an

Allocation of Ordinary Income

3. The Case of the Corporate Purchaser Attempting

to Preserve Losses ............................................................... 242

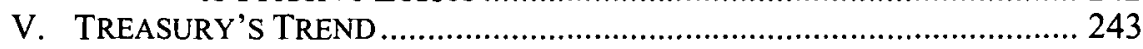

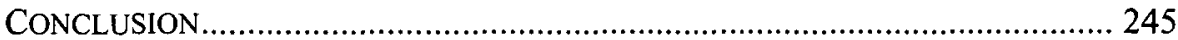

\section{INTRODUCTION}

The Treasury's "check-the-box regulations" govern the most basic of all corporate tax issues-namely, which entities are subject to the corporate tax. These fundamental regulations are practical, sensible, and (some would argue) indispensable. ${ }^{1}$ However, they are also unlawful.

The check-the-box regulations govern the classification of business entities as corporations or partnerships for federal tax purposes. ${ }^{2}$ In general, the earnings of an entity classified as a corporation are subject to two layers of tax: an entity-level tax - the corporate income tax - on the corporation's earnings; and an owner-level tax-the individual income tax-on distributions of earnings to the corporation's owners. ${ }^{3}$ Business entities not classified as corporations for tax purposes are generally classified as partnerships. ${ }^{4}$ Earnings of partnerships are subject to only a single level of tax at the owner level..$^{5}$ Thus, the tax classification of an entity as either a corporation or a partnership is the most basic of all corporate tax issues because it determines whether or not the entity is subject to the corporate income tax.

Section 7701(a)(3) of the Internal Revenue Code (the "Code") provides that "[t]he term 'corporation' includes associations, joint-stock companies, and

${ }^{1}$ See 1 William S. MCKeE et Al., Federal TaXation of Partnerships and PaRTNers I 3.08, at 3-102 (3d ed. 1997 \& Supp. 2002) (noting that the regulations "have evoked virtually universal approbation and support from private practitioners and taxpayers").

2 Treas. Reg. $\$ 301.7701-1$ to -3 (as amended in 2003).

${ }^{3}$ See 1 Boris I. Bittker \& James S. Eustice, Federal Income TaXation of CORPORATIONS AND SHAREHOLDERS 9 Tा 1.01-1.03, at 1-3 to 1-11 (7th ed. 2000 \& Supp. 2002) (describing in general how corporate earnings are taxed). In some cases, corporations are not subject to the double tax regime while in other cases, corporations are subject to unique taxing regimes. See id. I 1.06, at 1-25 to 1-29 (describing these special regimes).

${ }^{4}$ See I.R.C. $\S 7701(\mathrm{a})(2)$ (2000) (defining partnership as any business entity that is not otherwise determined to be a corporation, trust, or estate).

${ }^{5}$ See generally 1 MCKEE ET AL., supra note 1, I 1.01[1] (describing the taxation of income earned by partnerships). 
insurance companies." The federal tax law definition of "corporation" thus includes not only state law corporations but, more broadly, "associations." As a result, associations are taxable as corporations. The language in $\S 7701$ (a)(3) (and its predecessor statutes) has remained unchanged for over eighty-five years. $^{7}$

The question of which entities are included in the term "association" has confounded courts from the term's first appearance in the Code. ${ }^{8}$ The United States Supreme Court attempted to clear the confusion in the 1935 case Morrissey v. Commissioner, ${ }^{9}$ interpreting the term to mean any unincorporated entity that resembles a state law corporation. In determining whether an entity resembles a corporation, the Morrissey Court identified four relevant corporate factors: limited liability for owners, free transferability of ownership interests, perpetual existence of the entity, and a centralized management structure. ${ }^{10}$

Unfortunately, Morrissey did not end the confusion. Even after the U.S. Treasury promulgated regulations that applied Morrissey's corporate resemblance test in a relatively mechanical fashion, the test remained problematic. As a result, in 1996, the Treasury proposed the check-the-box regulations, defining the term "association" to mean any unincorporated business entity that elects to be taxed as a corporation. At the time, several commentators expressed concern that the regulations were invalid under the well-known Chevron doctrine. ${ }^{11}$ In particular, they argued that by giving the term "association" an elective definition, the regulations were incompatible with the statutory language, which suggested that Congress intended the term to have substantive meaning. The issue of whether the regulations satisfied the Chevron standard was the subject of significant debate and was even analyzed by the Joint Committee on Taxation. ${ }^{12}$ Notwithstanding these concerns, the Treasury soon promulgated the regulations in final form, apparently concluding that the regulations were valid under Chevron.

In this article, I argue that the check-the-box regulations are invalid because the Supreme Court's decision in Morrissey forecloses any re-interpretation of the term "association" by the Treasury. Accordingly, the focus on Chevron in

6 I.R.C. $\S 7701$ (a)(3) (emphasis added).

${ }^{7}$ Compare Revenue Act of $1918 \S 1$ (defining corporation as including "associations, joint-stock companies, and insurance companies"), with I.R.C. $\S 7701$ (a)(3) (same).

${ }^{8}$ See, e.g., Coleman-Gilbert Assoc. v. Comm'r, 76 F.2d 191, 193 (1st Cir. 1935) (describing the confusion surrounding the definition of the term "association").

9296 U.S. 344, 357-58 (1935).

10 Id. at 359.

${ }^{11}$ In very general terms, the Chevron doctrine requires that courts defer to any reasonable agency interpretation of an ambiguous statute. For a full discussion of Chevron, see infra Part I.

12 Staff of the JoInt Comm. ON TaXation, 105th Cong., Review OF Selected ENTITY Classification and Partnership TaX Issues 13-17 (Joint Comm. Print 1997) [hereinafter JCT REPORT]. 
the discussion of the validity of the regulations has been misplaced because, in assessing the validity of the regulations, one should never even reach the Chevron issue.

This conclusion is based on a trilogy of Supreme Court opinions holding that when the Court interprets a statutory term, that interpretation is binding on the executive branch and may be altered only by an act of Congress or a subsequent opinion of the Court. ${ }^{13}$ Therefore, these cases hold that, at least as far as the executive branch is concerned, a judicial interpretation of a statute is effectively incorporated into the underlying statute. Accordingly, because the check-the-box regulations' definition of association (i.e., any unincorporated entity that elects to be taxed as a corporation) is wholly inconsistent with the Morrissey definition (i.e., any unincorporated entity which resembles a corporation), the check-the-box regulations are invalid. To be clear, this article does not dispute the prevailing opinion that the regulations represent good tax policy; ${ }^{14}$ rather, it argues that the Treasury never had the authority to implement this policy in the first place.

After explaining why the check-the-box regulations are invalid, this article addresses several counter-arguments that, if successful, would save the regulations from invalidity. Ultimately, this article concludes that these counter-arguments are not fully persuasive.

Although this article focuses on only one specific regulatory action, the underlying issue has broad significance. It has been increasingly common for the Treasury to attempt to "fix" a Supreme Court interpretation that, for various reasons, the Treasury finds problematic. When faced with such a problematic interpretation, tax administrators have three choices: (1) propose

13 See Neal v. United States, 516 U.S. 284, $294-96$ (1996) (holding that a United States Sentencing Commission interpretation was invalid because it was inconsistent with the Court's prior interpretation); Lechmere, Inc. v. NLRB, 502 U.S. 527 (1992) (holding that a National Labor Relations Board interpretation was invalid because it was inconsistent with the Court's prior interpretations); Maislin Indus., U.S., Inc. v. Primary Steel, Inc., 497 U.S. 116, 134-35 (1990) (holding that an Interstate Commerce Commission interpretation was invalid because it was inconsistent with the Court's prior interpretation).

${ }^{14}$ See, e.g., 1 MCKEE ET AL., supra note 1, ๆ 3.08, at 3-102 (praising the policy behind the regulations). In the international arena, however, the regulations have given rise to some unfortunate consequences. The regulations have facilitated the use of hybrid entities, which are treated as flow-through entities for U.S. federal tax purposes and corporations for foreign tax purposes or vice versa. For discussions of the potential abuse of hybrids that has been facilitated by the issuance of the check-the-box regulations and the Treasury's responses thereto, see William L. Bricker, Jr. et al., Use of Hybrids in International Tax Planning: Past, Present and Future, 13 ST. JoHN's J. LEGAL COMMENT. 79 (1998); Thomas R. May, Warning: Hybrid Entities-Proceed With Caution, 86 TAX NoTES 533, 533-34 (Jan. 24, 2000), available at LEXIS 86 TN 533. The hybrid problem was not created by the regulations; however, the regulations did "make international tax-planning strategies that may not have been practical (due to the cost of implementation, probability of success, etc.) before their issuance both practical and attractive after their issuance." Id. at 533. 
legislation to Congress to fix the problem, (2) promulgate regulations that fix the problem in a taxpayer-adverse manner, or (3) promulgate regulations that fix the problem in a taxpayer-friendly manner. This article will demonstrate that option number (1) (go to Congress) is the only valid solution. The Treasury, however, has recently shown a tendency to choose option number (3) (fix the problem in taxpayer-friendly manner). This phenomenon likely results from the very restrictive standing rules governing taxpayer lawsuits that reduce or eliminate the likelihood of challenges to these invalid rules.

This article is divided into five parts. Part I lays out the administrative law landscape, describing the Chevron doctrine and its interaction with judicial precedent. Part II traces the history of the interpretation of the term "association" from its inception in the predecessor to $\S 7701$ (a)(3) up through the check-the-box regulations. Part III then applies administrative law principles to the check-the-box regulations, concluding that they are invalid. Part III also addresses the colorable arguments that could be made to save the regulations, but ultimately concludes that these arguments are not persuasive. Part IV considers how the Treasury could have issued invalid regulations in such an important and visible area of the law. In this discussion, Part IV describes the context in which a challenge to the regulations might arise and the practical consequences of a successful challenge. Finally, Part $\mathrm{V}$ argues that the Treasury has developed a trend of issuing taxpayer-friendly rules that are, like the check-the-box regulations, invalid because they are inconsistent with Supreme Court decisions directly on point. Part $V$ also discusses the implications of this trend.

\section{ADMINISTRATIVE LAW BACKGROUND}

\section{A. Pre-Chevron Law}

Prior to the Supreme Court's seminal 1984 decision in Chevron U.S.A., Inc. v. Natural Resource Defense Council, Inc., ${ }^{15}$ there was no coherent theory or doctrine regarding the judicial review of agency interpretations of ambiguous statutes. ${ }^{16}$ When considering agency interpretations, the level of respect the Court afforded the agency's view often varied significantly from case to case. ${ }^{17}$ In general, the cases could be split into two vastly different categories. Sometimes, the Court deferred to any agency interpretation that was reasonable in light of the statutory scheme. ${ }^{18}$ Under this method, which has been called

15467 U.S. 837 (1984).

16 See 1 Richard J. Pierce, JR., Administrative Law Treatise $\$ 3.1$ (4th ed. 2002 \& Supp. 2003) (describing pre-Chevron guidelines for judicial review of agency interpretations); Thomas W. Merrill, Judicial Deference to Executive Precedent, 101 Y ALE L.J. 969, 972-75 (1992) (discussing the pre-1984 judicial review guidelines).

17 See Merrill, supra note 16, at 972.

18 See, e.g., NLRB v. Hearst Publ'ns, Inc., 322 U.S. 111 , 131 (1944) (upholding National Labor Relations Board's interpretation of the term "employee" in the National Labor 
the deferential model, the Court would not actively interpret the statute at issue-rather, its "role was limited to determining whether the agency's interpretation was reasonable." 19 In other words, under this model, the Court would not seek to find the single best interpretation but would merely ensure that the agency's position was within the universe of rational interpretations and not arbitrary or capricious. ${ }^{20}$ In these instances, the agency, rather than the judiciary, would have primary interpretive authority. ${ }^{21}$

In other cases, the Court would take primary interpretive authority and independently review the statute in an attempt to find the single best interpretation. ${ }^{22}$ Under this method, known as the independent judgment model, the Court would actively interpret the statute, rather than merely determining whether the agency's proffered interpretation was reasonable. ${ }^{23}$

Under the independent judgment model, even though the Court had primary interpretive authority, the agency's view was not irrelevant. Because of the agency's familiarity with the statutory scheme and its underlying policies, the agency's "view of the proper meaning [was] a factor in the court's analysis, [and was] given whatever persuasive effect it appear[ed] to merit in the

Relations Act as including newsboys, even though newsboys were characterized as independent contractors for other purposes, because the interpretation had "a reasonable basis in law"); see also PIERCE, supra note 16, § 3.1, at 139 (observing that, in certain instances prior to Chevron, the Court would defer to any interpretation promulgated by an agency so long as the interpretation was reasonable); Cynthia R. Farina, Statutory Interpretation and the Balance of Power in the Administrative State, 89 CoLuM. L. REV. 452, 454 (1989) (same). Even though the deferential model was, in general, sporadically applied by courts, it was consistently applied where Congress made an explicit delegation of law-making authority to an agency. See, e.g., United States v. Morton, 467 U.S. 822, 834 (1984); Schweiker v. Gray Panthers, 453 U.S. 34, 44 (1981); Batterton v. Francis, 432 U.S. 416, 425 (1977); Am. Tel. \& Tel. Co. v. United States, 299 U.S. 232, 235-37 (1936) (finding clear congressional intent to delegate interpretive authority to the respective agencies and applying the deferential model); see also Kenneth A. Bamberger, Provisional Precedent: Protecting Flexibility in Administrative Policymaking, 77 N.Y.U. L. REV. 1272, 1285 (2002) ("[Chevron] simply expanded the separation-of-powers model that the Supreme Court had applied since the beginning of the twentieth century to instances in which Congress explicitly assigned to agencies the power to construe regulatory statutes.").

19 See Rebecca Hammer White, The Stare Decisis "Exception" to the Chevron Deference Rule, 44 FLA. L. REV. 723, 729 (1992).

${ }^{20}$ Farina, supra note 18, at 454.

${ }^{21}$ See id. at 453-54.

22 See, e.g., NLRB v. Bell Aerospace, 416 U.S. 267 (1974) (independently determining that the term "employees" in the National Labor Relations Act did not include buyers despite the National Labor Relations Board's conclusion to the contrary); see also PIERCE, supra note $16, \S 3.1$ (describing how, in certain instances prior to Chevron, the Court would independently interpret a statute in a manner contrary to an agency's reasonable interpretation); Farina, supra note 18, at 453-54 (same).

${ }^{23}$ Farina, supra note 18, at 453-54. 
circumstances." 24 At all times under this model, however, it was the Court that would decide the statute's single best meaning, even if the Court ultimately agreed with the agency's position. ${ }^{25}$

Prior to Chevron, it was often impossible to predict in any given case whether the Court would apply the independent judgment model or the deferential model. ${ }^{26}$ Furthermore, it was often difficult to characterize a decision as employing one or the other type of analysis. ${ }^{27}$ The leading administrative law treatise described the hopelessly muddled state of affairs at the time: "The Court... substitutes judgment in some cases and uses the reasonable test [i.e., the deferential review model] in other cases, without providing any guide as to what actuates its choices." 28

\section{B. Chevron's Impact-Victory for the Deferential Model?}

In Chevron, the Court appeared to adopt conclusively the deferential model, articulating the precise steps a court should take in reviewing agency interpretations. When a court is faced with an agency interpretation of an agency-administered statute, Chevron instructed that the first step is for the court to determine whether Congress "has directly spoken to the precise question at issue." 29 Under this step one, a court should look to the words of the statute and "employ[] ... traditional tools of statutory construction" to ascertain whether "Congress had an intention on the precise question at issue." ${ }^{30}$ If so, the clear will of Congress as expressed in the statute controls, notwithstanding a contrary interpretation asserted by the agency. ${ }^{31}$

Step one is thus consistent with both the independent judgment and deferential models. If a case is concluded at that step, it means that the court has determined that the statute has a clear meaning. Under the independent judgment model, the court would have independently adopted that same meaning, and under the deferential model, the court would find "unreasonable" any contrary meaning.

If step one yields the determination that "Congress has not directly addressed the precise question at issue," Chevron then instructed the Court to

${ }^{24} I d$. at 454

${ }^{25}$ Id. at 453 (explaining that, under the independent judgment model, "the court exercises its own judgment to determine de novo what the statute means").

26 Id. at 454-55.

27 See Merrill, supra note 16, at 972 (describing pre-Chevron confusion and concluding that, although there existed cases falling neatly within the independent judgment model or the deferential model, "in practice, deference existed along a sliding scale, bridging these outer limits").

${ }^{28}$ KenNeth Culp Davis, Administrative Law Treatise 375 (2d ed. 1958).

29 Chevron U.S.A., Inc. v. Natural Res. Def. Council, Inc., 467 U.S. 837, 842 (1984).

${ }^{30} \mathrm{Id}$. at 843 n.9.

${ }^{31}$ Id. at $842-43$. 
move on to step two. ${ }^{32}$ In step two, a court "does not simply impose its own construction on the statute, as would be necessary in the absence of an administrative interpretation." 33 Rather, the court seeks to determine simply "whether the agency's [position] is based on a permissible construction of the statute." 34 To determine that an agency position is permissible, "[t]he court need not conclude that the agency construction was the only one it permissibly could have adopted to uphold the construction, or even the reading the court would have reached if the question initially had arisen in a judicial proceeding." 35 Rather, the court's responsibility is to determine whether the agency's position represents a "reasonable policy choice" in light of the congressional mandate articulated in the statute..$^{36}$ Thus, under step two, a court's task is not to determine the single best interpretation of an ambiguous statute as it would under the independent judgment model; its task is to determine only whether the agency's position is a reasonable one. ${ }^{37}$

Therefore, although step one is consistent with both the independent judgment model and the deferential model, the deference shown to any reasonable interpretation under step two suggests that the deferential model won the day. ${ }^{38}$ As discussed below, however, the 2001 Mead decision has now made clear that the independent judgment model did survive Chevron. ${ }^{39}$

The doctrinal basis for Chevron deference has been the subject of significant

32 Id. at 843.

${ }^{33} \mathrm{Id}$. (footnote omitted).

$34 \mathrm{Id}$. (footnote omitted).

${ }^{35}$ Id. at 843 n.11.

36 Id. at 845 .

37 The Supreme Court has never made clear how a court is supposed to determine when an interpretation plausible enough to survive step one is nonetheless unreasonable under Chevron step two. See Ronald M. Levin, The Anatomy of Chevron: Step Two Reconsidered, 72 CHI.-KENT L. REV. 1253, 1260 (1997) (arguing that the Court's step two standard is vague and "seem[s] to verge on internal incoherence"). The leading view appears to be that step two deals with an agency's decisionmaking process in arriving at an interpretation, focusing primarily on whether the agency adequately considered the matter at hand as opposed to making an arbitrary and capricious decision. See Animal Def. Fund v. Glickman, 204 F.3d 229, 234 (D.C. Cir. 2000) (concluding that step two is designed to strike down interpretations that, while plausible under the statute, were arbitrary and capricious); see also PIERCE, supra note 16, § 3.6, at 11 (2003 Supp.) (explaining that, in applying step two, the Supreme Court has been "evaluating the adequacy of an agency's reasoning process, thereby demonstrating the convergence of the 'reasonableness' test in step two of Chevron with the duty to engage in reasoned decisionmaking"); Levin, supra, at 1263 (claiming that the D.C. Circuit "has transformed the Chevron step two question of whether the agency action was 'reasonable' into a question of whether it was 'reasoned"').

38 See Farina, supra note 18, at 455 (concluding that Chevron "endorsed [the] deferen[tial model] in emphatic terms"); White, supra note 19, at 730 (stating that Chevron endorsed the deferential model).

39 See infra Part I.C. 
debate among scholars. ${ }^{40}$ Some suggest that the doctrine has its roots in constitutional separation of powers principles, ${ }^{41}$ while others argue that it arose from judicial common law. ${ }^{42}$ The prevailing theory, however, based on language in recent Supreme Court cases ${ }^{43}$ is that Chevron deference is based on presumed congressional intent. ${ }^{44}$ Under this theory, in the absence of a specific directive from Congress on how agency interpretations should be reviewed by courts, the Court has assumed the default rule that Congress desires that politically accountable agencies (rather than the politically insulated courts) be entrusted with primary interpretive responsibility with regard to ambiguities and gaps within agency-administered statutes. ${ }^{45}$ This assumption (i.e., that Congress generally wants agencies to bear primary interpretive responsibility), however, has been described by some scholars as a fiction because it appears that "Congress rarely formulates an intent about who will decide particular questions of statutory meaning." 46 In fact, there is some evidence to suggest that legislators might actually prefer that courts, rather than agencies, reconcile ambiguities and gaps in statutes. ${ }^{47}$

40 See Thomas W. Merrill \& Kristin E. Hickman, Chevron's Domain, 89 GEO. L.J. 833, 863-73 (2002) (discussing the debate surrounding the basis for Chevron).

${ }^{41}$ See Douglas W. Kmiec, Judicial Deference to Executive Agencies and the Decline of the Nondelegation Doctrine, 2 ADMIN. L.J. 269, 287-90 (1988); Richard J. Pierce, Jr., Reconciling Chevron and Stare Decisis, 85 GEO. L.J. 2225, 2227 (1997); Kenneth W. Starr, Judicial Review in the Post-Chevron Era, 3 YALE J. ON REG. 283, 308 (1986).

42 See Maureen B. Callahan, Must Federal Courts Defer to Agency Interpretations of Statutes? A New Doctrinal Basis for Chevron U.S.A. v. Natural Resources Defense Council, 1991 WIS. L. REV. 1275, 1289-94; William N. Eskridge, Jr. \& Philip P. Frickey, Quasi-Constitutional Law: Clear Statement Rules as Constitutional Lawmaking, 45 VAND. L. REV. 593, 618-19 (1992); David M. Hasen, The Ambiguous Basis of Judicial Deference to Administrative Rules, 17 YALE J. ON REG. 327, 357-62 (2000).

43 See, e.g., United States v. Mead Corp., 533 U.S. 218, 226-27 (2001) (applying Chevron deference "when it appears that Congress delegated authority to the agency generally to make rules carrying the force of law, and that the agency interpretation claiming deference was promulgated in the exercise of that authority").

44 See Merrill \& Hickman, supra note 40, at 870-72 (explaining that "the congressionalintent theory is the best of the three explanations for the legal foundation of Chevron deference").

45 Although the Chevron Court focused on an executive agency's responsiveness to the President's influences, see Chevron U.S.A., Inc. v. Natural Res. Def. Council, Inc., 467 U.S. 837,865 (1984), it is clear that executive agencies are also responsive to influence by Congress and lobbyists. Einer Elhauge, Preference-Estimating Statutory Default Rules, 102 Colum. L. REV. 2027, 2149-50 (2002).

${ }^{46}$ Farina, supra note 18, at 471; see also Elhauge, supra note 45, at 2132 (arguing that evidence of congressional intent to delegate interpretive authority to administrative agencies absent explicit authorization to do so is "weak" or "fictional").

47 See Farina, supra note 18, at 473-74 (describing the near passage of the Bumpers Amendment in 1975, which would have required federal courts to review all matters of law de novo). 
Despite these suspect underpinnings, the Chevron doctrine has generally been considered wise as a matter of policy. ${ }^{48}$ The Chevron doctrine has been described as furthering a number of policy goals, ${ }^{49}$ two of which are most significant in regard to this article. First, by giving the executive branch primary interpretive authority vis-à-vis the judicial branch with respect to ambiguities and gaps left by Congress, Chevron allocates policy-making power towards a politically accountable branch and away from a politically insulated branch. $^{50}$

Second, Chevron gives agencies the flexibility to change and adapt their policies to reflect the current state of affairs and political attitudes. ${ }^{51}$ Under the independent judgment model, the Court would interpret an ambiguous term on its own, and the Court's interpretation would be binding on the public and the executive branch by virtue of stare decisis. ${ }^{52}$ Thus, under this model, if the Court adopts interpretation $X$, that interpretation becomes binding precedent even if the term is susceptible to a different interpretation. ${ }^{53}$ If an agency subsequently adopts interpretation $Y$, that interpretation would be invalid, at

48 See, e.g., Jerry L. Mashaw, Greed, Chaos and Governance 152-53 (1997); Callahan, supra note 42, at 1289; Michael Stokes Paulsen, The Most Dangerous Branch: Executive Power to Say What the Law Is, 83 GEo. L.J. 217, 333-34 (1993); Richard J. Pierce, Jr., Political Control Versus Impermissible Bias in Agency Decisionmaking: Lessons from Chevron and Mistretta, 57 U. CHI. L. REV. 481, 486 (1990); Antonin Scalia, Judicial Deference to Administrative Interpretations of Law, 1989 DUKE L.J. 511, 517-20; Peter L. Strauss, One Hundred Fifty Cases Per Year: Some Implications of the Supreme Court's Limited Resources for Judicial Review of Agency Action, 87 COLUM. L. REV. 1093, 1121-22 (1987); Cass Sunstein, Law and Administration After Chevron, 90 Colum. L. Rev. 2071, 2091-2104 (1990) (extolling the policy virtues of Chevron). This view that Chevron is a wise policy choice is by no means unanimous. See, e.g., Farina, supra note 18, at 515-16; Merrill, supra note 16, at 998; Mark Seidenfeld, A Syncopated Chevron: Emphasizing Reasoned Decisionmaking in Reviewing Agency Interpretations of Statutes, 73 TEX. L. REV. $83,120-25$ (1994) (contending that Chevron is not sound public policy).

49 See, e.g., Pierce, supra note 41 , at $2229-37$ (discussing six goals furthered by Chevron).

${ }^{50}$ See id. at 2229 ("[A]gencies are in a position below Congress but above courts in the institutional hierarchy in the policymaking context.").

${ }^{51}$ See Chevron U.S.A., Inc. v. Natural Res. Def. Council, Inc., 467 U.S. 837, 863-64 (1984) (" $[\mathrm{T}] \mathrm{he}$ agency, to engage in informed rulemaking, must consider varying interpretations and the wisdom of its policy on a continuing basis."); see also Smiley v. Citibank (S.D.), N.A., 517 U.S. 735, 742 (1996) ("[T]he whole point of Chevron is to leave the discretion provided by the ambiguities of a statute with the implementing agency."); Rust v. Sullivan, 500 U.S. 173, 186-87 (1991) (emphasizing that agencies must be allowed to adapt their interpretations to adapt to changing circumstances).

52 See Patterson v. McLean Credit Union, 491 U.S. 164, 172-75 (1989) (acknowledging the stare decisis effect on the executive branch).

53 See Pierce, supra note 41, at 2225 (explaining that when courts "impose[] their own constructions on ambiguous agency-administered statutes... [they] create binding precedent"). 
least to the extent that $Y$ is inconsistent with $X$, even if $Y$ is an entirely reasonable interpretation. ${ }^{54}$ Thus, the independent judgment model results in a lock-in of a single interpretation, subject to change only by Congress. ${ }^{55}$

On the other hand, when the Court implements the Chevron doctrine, there is no such lock-in effect. When the Court applies Chevron, it results in a very limited stare decisis effect. ${ }^{56}$ For example, assume that the Court determines that a particular term is ambiguous under Chevron step one and that a particular agency interpretation (interpretation $X$ ) is permissible under Chevron step two. The only stare decisis effects resulting from such a determination are the following: (1) the particular term is ambiguous under Chevron step one, ${ }^{57}$ and (2) interpretation $X$ was reasonable under Chevron step two. ${ }^{58}$ Stare decisis would have no impact on the validity of subsequent inconsistent interpretation $Y$ promulgated by the agency. ${ }^{59}$ So long as that interpretation passes Chevron step two, the latter interpretation would be valid. ${ }^{60}$

\section{United States v. Mead: The Return of the Independent Judgment Model}

Although Chevron appeared to adopt conclusively the deferential model, the recent Supreme Court decision in United States v. Mead Corp. ${ }^{61}$ has suggested otherwise. Until Mead, it was not entirely clear what types of agency guidance were entitled to Chevron deference. ${ }^{62}$ Agency guidance can take a variety of

54 See, e.g., Neal v. United States, 516 U.S. 284, 295-96 (1996) (holding invalid an agency interpretation that conflicted with the Court's prior interpretation made under the independent judgment model).

55 See United States v. Mead Corp., 533 U.S. 218, 247 (2001) (Scalia, J., dissenting) (stating that when the Court interprets an ambiguous term under the independent judgment model, "ambiguity (and hence flexibility) will cease with the first judicial resolution").

${ }^{56}$ See id. at 248 (claiming that under Chevron, "the court does not purport to give the statute a judicial interpretation").

${ }^{57}$ See id. (maintaining that, when Chevron applies, the only judgment of the court that is "final and irreversible" is the court's "identif[ication of] the scope of the statutory ambiguity").

58 See id. (asserting that, when Chevron applies, the Court's approval of one reasonable agency interpretation of an ambiguous statute will not foreclose a later inconsistent, reasonable agency interpretation).

${ }^{59}$ See id.

${ }^{60}$ See id. ("[W]hen the agency's authoritative interpretation comes within the scope of that ambiguity -and the court therefore approves it-the court will not be 'overruling' the court's decision when it later decides that a different interpretation (still within the scope of ambiguity) is preferable.").

61533 U.S. 218.

62 John F. Coverdale, Chevron's Reduced Domain: Judicial Review of Treasury Regulations and Revenue Rulings After Mead, 55 ADMIN. L. REv. 39, 46 (noting that, until recently, the scope of Chevron was not clear). Although the Court had limited Chevron deference to cases where an interpretation was made by the agency charged with administering the particular statute, see Adams Fruit Co. v. Barrett, 494 U.S. 638, 649 
forms, from the most formal and general (e.g., regulations) to the most informal and specific (e.g., litigating positions). ${ }^{63}$ An expansive view of interpretations that qualify for Chevron deference would mean that many kinds of agency interpretations would fall within the scope of Chevron.64 On the other hand, a narrow view would shrink Chevron's scope by limiting the kinds of agency interpretations eligible for deference. ${ }^{65}$ Closely related to the issue of Chevron's scope is the question of what sort of respect, if any, should be afforded agency interpretations that do not qualify for Chevron deference.

In Mead, the Court provided some guidance on these issues. ${ }^{66}$ In that case, the United States Customs Service ("Customs") interpreted a statutory term in a tariff classification ruling. ${ }^{67}$ The threshold issue in Mead was whether the tariff classification ruling was an agency interpretation that qualified for Chevron deference. ${ }^{68}$

The Court first determined that not all authoritative agency determinations triggered deference under Chevron. ${ }^{69}$ Rather, the Court found that an agency interpretation would trigger Chevron deference only in two separate instances. First, Chevron deference is triggered when there is an "express delegation [by Congress] of specific interpretive authority." 70 Second, Chevron deference is triggered when it "appears that Congress delegated authority to the agency generally to make rules carrying the force of law, and that the agency

(1990), and to cases where the agency had the statutory power to promulgate rules and regulations, see EEOC v. Arabian Am. Oil Co., 499 U.S. 244, 250-51 (1991), it was unclear until Mead what types of interpretations by these agencies would not be given Chevron deference. See Coverdale, supra, at 46-47 ("As late as 2000, a plausible argument could be advanced that as a matter of positive law, Chevron deference applied to all positions that represented the official view of an agency charged with the administration of a statute and empowered to promulgate rules and regulations.").

${ }^{63}$ See generally Peter L. Strauss, The Rulemaking Continuum, 41 DUKE L.J. 1463, 1463 66 (describing the various forms in which agency positions are expressed).

${ }^{64}$ See Merrill \& Hickman, supra note 40, at 835 (explaining that the scope of "Chevron's domain" depends on "what sorts of agency interpretations [are subject to] the mandatory deference doctrine of Chevron").

${ }^{65}$ See id.

66 The Supreme Court decision in Christensen v. Harris County, 529 U.S. 576 (2000), foreshadowed the holding in Mead. In Christensen, the issue was whether an agency position expressed in an opinion letter qualified for Chevron deference. Id. at 586. The five-member majority concluded that only agency positions that have the "force of law" so qualify, and that the position in question did not have the force of law. Id. at 587 .

${ }^{67}$ United States v. Mead Corp., 533 U.S. 218 (2001). The specific issue was whether the statutory term "[bound] [d]iaries" included day planners, described by the Court as "threering binders with pages having room for notes of daily schedules and phone numbers and addresses, together with a calendar and suchlike." Id. at 224-25.

$68 \mathrm{Id}$. at 226.

69 See id. at 227.

${ }^{70} \mathrm{Id}$. at 229. 
interpretation claiming deference was promulgated in the exercise of that authority." 71 Thus, in order for an agency interpretation to obtain the benefit of Chevron deference in the absence of a specific directive from Congress, the agency must show that Congress gave it a general grant of authority to make rules having the effect of law in the particular form in which the interpretation was issued.

The Court went on to provide that such a general grant of authority "may be shown in a variety of ways, as by an agency's power to engage in adjudication or notice-and-comment rulemaking, or by some other indication of a comparable congressional intent." ${ }^{2}$ The Court reasoned that it could be assumed "that Congress contemplates administrative action with the effect of law when it provides for a relatively formal administrative procedure tending to foster the fairness and deliberation that should underlie a pronouncement of such force." 73

Turning to the tariff classification rulings at issue, the Court concluded that there was no specific congressional delegation to Customs to issue these rulings with the force of law. ${ }^{74}$ Furthermore, although the Court found that Customs had been given a general grant of authority to issue regulations with the force of law, it found no such authority with respect to tariff classification rulings. ${ }^{75}$ In reaching this conclusion, the Court noted that the rulings were issued without notice and comment, were treated by Customs as not binding on third parties, and were issued in large quantities by forty-six offices scattered around the United States. ${ }^{76}$

After concluding that the tariff classification rulings did not qualify for Chevron deference, the Court next considered what level of respect, if any, was to be afforded the rulings in interpreting the statutory language at issue. ${ }^{77}$ The Court concluded that these agency interpretations should be given an amount of respect proportional to their "power to persuade," citing the 1944 case Skidmore v. Swift \& $\mathrm{Co}^{78}$ As a result, the Mead Court affirmed the continuing vitality of the independent judgment model in cases where the agency interpretation failed to qualify for Chevron deference. In these cases, the court will bear primary interpretive responsibility, and the weight given to the agency's view will depend "upon the thoroughness evident in its consideration, the validity of its reasoning, its consistency with earlier and later pronouncements, and all those factors which give it power to persuade ...."79

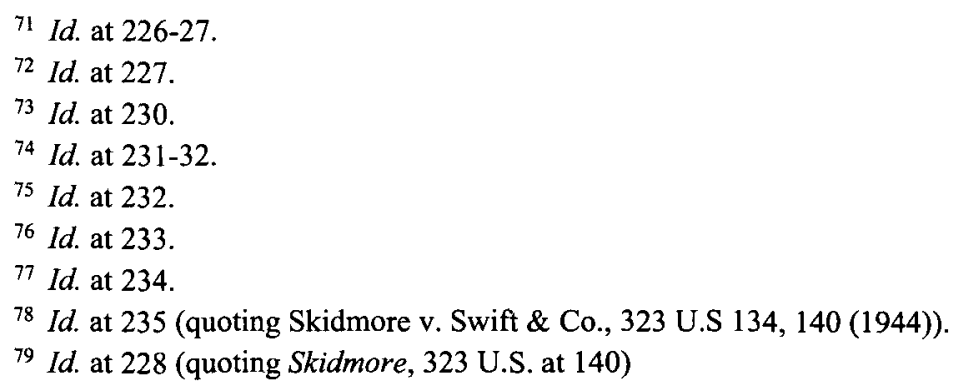


Unlike Chevron deference, "Skidmore respect" 80 is not based on any implied delegation by Congress, since such implied delegation must necessarily have been found lacking or else Chevron rather than Skidmore would have applied. ${ }^{81}$ Rather, Skidmore respect is based in judicial common law and on the notion that the view of an agency - expert in the relevant field and familiar with the statutory scheme-is a relevant consideration. ${ }^{82}$

Therefore, Mead indicates a two-tier system for agency interpretations. With respect to agency interpretations in a format that Congress intends to have the force of law (Mead-qualified interpretations), an agency position that passes Chevron's deferential standard will control. With respect to agency interpretations in any other format (non-Mead-qualified interpretations), the

${ }^{80}$ Courts have commonly used the phrase "Skidmore deference" to refer to. the amount of respect accorded agency interpretations under Skidmore. See, e.g., Scafar Contracting, Inc. v. Sec'y of Labor, 325 F.3d 422, 428 (3d Cir. 2003) (discussing an agency interpretation that is sound when reviewed with Skidmore deference). This phrase, however, is an oxymoron. Under Skidmore, the Court is charged with the primary interpretive responsibility with regard to an ambiguous provision. See Skidmore, 323 U.S. at 140 (indicating that the agency interpretation in question was "not controlling upon the court by reason of [its] authority"); Clark Byse, Scope of Judicial Review in Informal Rulemaking, 33 ADMIN. L. REV. 183, 192 (1981) (stating that under the Skidmore formulation, the agency interpretation is only looked to for guidance). In determining the single best meaning of the provision, the court may or may not take into account the position of the expert agency, depending on the facts and circumstances. See Skidmore, 323 U.S. at 140 (holding that, while the agency interpretation in question was "not controlling upon the courts by reason of [its] authority," the interpretation nevertheless could be resorted to "for guidance" and that the weight to be given such guidance depended upon the agency interpretation's "power to persuade"). Thus, the court never technically defers to the agency position under Skidmore even if the court ultimately adopts the position; the agency position is mere evidence considered by the court in its attempt to determine the single best interpretation. See Mead Corp., 533 U.S. at 247-48 (Scalia, J., dissenting) (explaining that while Skidmore deference gives some weight to the agency position, the Court ultimately decides the meaning of the statute). Under Chevron, a true deference doctrine, the Court does not purport to interpret an ambiguous statute, instead deferring to any reasonable agency interpretation. See id. at 247 (indicating that the Court does not make a binding interpretation under Chevron, but only approves the agency decision).

81 See Mead Corp., 533 U.S. at 229.

82 See Skidmore, 323 U.S. at 139 (emphasizing that agency interpretations are "based upon more specialized experience and broader investigations and information than is likely to come to a judge in a particular case"). Other reasons have been cited for treating agency positions with respect under Skidmore. Skidmore itself also recognized a value in nationally uniform agency interpretations. See id. at 140 (arguing that interpretations should be uniform unless there is a good reason); Michael Asimow, The Scope of Judicial Review of Decisions of California Administrative Agencies, 42 UCLA L. REV. 1157, 1203-06 (1995) (asserting that judicial deference to agencies results in greater uniformity). In addition, some have cited inter-branch comity as a basis for Skidmore respect. See, e.g., Coverdale, supra note 62, at 55 (claiming Skidmore respect "reflects an elementary demand of interbranch comity which courts have long recognized"). 
Court will ultimately decide the proper meaning of the statute, providing the agency view with some level of respect depending on context. As a result, it is now clear that the independent judgment model survived Chevron and applies to statutory interpretation cases that are decided without the benefit of a Meadqualified agency position. ${ }^{83}$

\section{The Conflict Between Chevron and Stare Decisis}

Prior to Chevron, when the Court interpreted a statutory term under the independent judgment model, such an interpretation would be given stare decisis effect until Congress amended the statute. ${ }^{84}$ In fact, the Court has applied a "super-strong" presumption of correctness with regard to statutory interpretation precedent. ${ }^{85}$ The foundation for this presumption is that, unlike in the constitutional interpretation context, Congress can always amend the law if it disagrees with the Court's interpretation. ${ }^{86}$

The Court's strong reluctance to overturn its statutory interpretation precedent is therefore based on the presumption that Congress approves every Supreme Court interpretation unless Congress amends the underlying statute..$^{87}$ This presumption, like the presumption that underlies Chevron (that Congress wants agencies to bear primary interpretive responsibility), ${ }^{88}$ is questionable. ${ }^{89}$

${ }^{83}$ In fact, given the ambiguous "force of law" standard set forth by Mead, one could argue that the case returns administrative law to the pre-Chevron era when the level of judicial deference given to an agency's action was unpredictable. See David J. Barron \& Elena Kagan, Chevron's Nondelegation Doctrine, 2001 Sup. CT. REv. 201, 226.

${ }^{84}$ See, e.g., Patterson v. McLean Credit Union, 491 U.S. 164, 172-75 (1989) (holding that stare decisis is important in areas of statutory interpretation because Congress remains free to act on the Court's decisions).

${ }^{85}$ See, e.g., Neal v. United States, 516 U.S. 284, 295 (1996) (describing the great weight of stare decisis in the area of statutory construction); Hilton v. S.C. Pub. Rys. Comm'n, 502 U.S. 197, 202 (1991) (finding that stare decisis "has special force in the area of statutory interpretation"); Patterson, 491 U.S. at 172 (explaining that "the burden borne by the party advocating the abandonment of an established precedent is greater where the Court is asked to overrule a point of statutory construction"); see also William N. Eskridge, Jr., Overruling Statutory Precedents, 76 GEO. L.J. 1361, 1362-63 (1988).

${ }^{86}$ See Neal, 516 U.S. at 295-96 (explaining that the basis for the super-strong presumption is the notion that Congress is free to change the court's interpretation of the legislation); Hilton, 502 U.S. at 202 (observing that with statutory interpretation, unlike constitutional interpretation, Congress can override the judgment of the courts).

${ }^{87}$ See Hilton, 502 U.S. at 202 (suggesting that if Congress does not alter legislation in response to a judicial decision, it has made a choice not to do so).

${ }^{88}$ See supra text accompanying notes $44-47$.

${ }^{89}$ See William N. Eskridge, Jr., Interpreting Legislative Inaction, 87 MicH. L. REV. 67, 98-103 (1988) (casting doubt upon the ability to presume intent from the collective inaction of members of Congress). Eskridge also criticizes the super-strong presumption of correctness on other grounds. See id. at 95-98 (questioning the relevance of "subsequent" legislative intent); $i d$. at 104-08 (arguing that the super-strong presumption may exacerbate 
As William Eskridge has noted, it is often impossible to draw inferences of legislative support from inertia since "the structure of Congress makes it far more likely that something will not happen (inaction) than it will (action)." 990 Nevertheless, it is clear that the effect of stare decisis in statutory interpretation cases is quite formidable. ${ }^{91}$

What happens when an agency interprets a term in a manner that would otherwise be permissible under Chevron step two but is inconsistent with a prior Supreme Court interpretation ${ }^{92}$ of that term? This issue presents a conflict between stare decisis and Chevron. ${ }^{93}$ If Chevron controls, the reasonable agency interpretation would prevail. Alternatively, if stare decisis controls, the prior Supreme Court determination would prevail since the later agency interpretation, even if reasonable, would be inconsistent with binding precedent. The Court has held in a trilogy of cases that stare decisis controls in this conflict. ${ }^{94}$ These three cases therefore conclude that Supreme Court

existing dysfunctions in the legislative process).

90 Id. at 98.

91 See, e.g., Patterson v. McLean Credit Union, 491 U.S. 164, 173-74 (1989) (explaining that statutory precedents are generally overruled where there has been an "intervening development of the law").

92 To be clear, when I use the term "Supreme Court interpretation," I mean interpretations by the Court under the independent judgment model, as opposed to interpretations that were merely approved of by the Court under the deferential model. When the Court implements the deferential model, it results in a very limited stare decisis effect. See supra text accompanying notes 56-60. Unlike decisions made under the independent judgment model, the Court does not determine the single best meaning of a term. Rather, the Court merely decides whether the term is reasonably susceptible to the agency's proffered interpretation. This does not foreclose the possibility that a different interpretation may be permitted in future cases.

${ }_{93}$ Pierce, supra note 41 , at 2226 . This conflict could arise only between a prior judicial interpretation and Chevron step two, not between a prior judicial interpretation and Chevron step one. If the statutory term admits of only one interpretation (i.e., the prior judicial interpretation), the inconsistent agency interpretation would be struck down under Chevron step one. Because the outcome would be the same regardless of whether Chevron or stare decisis controlled, there would be no conflict. See id. at 2225.

${ }^{94}$ See Neal v. United States, 516 U.S. 284, 290 (1996) (holding that a United States Sentencing Commission interpretation was invalid because it was inconsistent with the Court's prior interpretation); Lechmere, Inc. v. NLRB, 502 U.S. 527, 536-37 (1992) (holding that a National Labor Relations Board interpretation was invalid because it was inconsistent with the Court's prior interpretation); Maislin Indus., U.S., Inc. v. Primary Steel, Inc., 497 U.S. 116, 130-31 (1990) (holding that the Interstate Commerce Commission's interpretation was inconsistent with the Court's prior interpretation); see also United States v. Mead Corp., 533 U.S. 218, 247 (2001) (Scalia, J., dissenting) (citing Neal, Lechmere, and Maislin for the proposition that "[o]nce the court has spoken, it becomes unlawful for the agency to take a contradictory position; the statute now says what the court has prescribed"); Golden State Transit Corp. v. City of Los Angeles, 493 U.S. 103, 112 (1989) ("A rule of law that is the product of judicial interpretation of a vague, ambiguous, or 
interpretations trump the deference owed under Chevron. As a result, preChevron Supreme Court interpretations are binding on the executive branch and can be altered only if Congress amends the statute or if the Court decides to overrule its prior interpretation despite its super-strong presumption of correctness.

For example, in the 1996 case of Neal v. United States, the most recent case in this trilogy, the Court considered the meaning of the statutory term "mixture or substance" in determining the weight of lysergic acid diethylamide ("LSD") to be taken into account for criminal sentencing purposes. ${ }^{95}$ The Court had previously interpreted the term in Chapman $v$. United States to include the actual weight of blotter paper, ${ }^{96}$ even though such interpretation would result in a "significant disparity of punishment meted out to LSD offenders relative to other narcotics traffickers." "97 Two years after Chapman, the United States Sentencing Commission (the "Commission") took the position that each dose

incomplete statutory provision is no less binding than a rule that is based on the plain meaning of the statute."); PiERCE, supra note 16, $\S 3.6$, at 185 ("The [Supreme] Court has consistently held that a Supreme Court precedent trumps Chevron deference."); Bamberger, supra note 18, at 1293-94 ("[E]ven after Chevron... court precedents always trump Chevron deference."); Einer Elhauge, Preference-Eliciting Statutory Default Rules, 102 Colum. L. REv. 2162, 2262 (2002) (stating that "the Chevron doctrine of deference to agency interpretations does not apply when the agency deviates from a court's own precedent interpreting the statute"); Merrill, supra note 16, at 989 (arguing that Maislin "emphatically rejected the idea that an agency might disregard a previous judicial construction of a statute, at least when it is a precedent of the Supreme Court"); Merrill \& Hickman, supra note 40, at 915 ("The Supreme Court has consistently ruled that agency interpretations of statutes that deviate from the Court's own precedents are not entitled to Chevron deference."); Pierce, supra note 41, 2226 (citing Neal, Lechmere, and Maislin as the basis for the "mechanical rule[]" that "Supreme Court precedents always trump the deference owed under Chevron").

Although the Supreme Court has concluded that its own precedents trump Chevron, it has frequently upheld agency interpretations that are at odds with existing lower court precedent. See, e.g., Sutton v. United Air Lines, 527 U.S. 471, 477, 482 (1999). The circuit courts are divided on the issue of whether a prior interpretation of a term by the circuit will foreclose any subsequent inconsistent agency interpretation with regard to that circuit. Compare Satellite Broad. \& Communications Ass'n of Am. v. Oman, 17 F.3d 344, 348 (11th Cir. 1994) (holding that its precedent interpreting an ambiguous statutory term does not foreclose subsequent inconsistent agency interpretation of that term), with Bankers Trust N.Y. Corp. v. United States, 225 F.3d 1368, 1376 (Fed. Cir. 2000) (holding that precedent interpreting an ambiguous statutory term forecloses subsequent inconsistent agency interpretation of that term), Indus. Turnaround Corp. v. NLRB, 115 F.3d 248, 254 (4th Cir. 1997) (same), Aguirre v. INS, 79 F.3d 315, 317 (2d Cir. 1996) (same), and BPS Guard Services, Inc. v. NLRB, 942 F.2d 519, 523 (8th Cir. 1991) (same).

95 516 U.S. at $288-90$.

96 Chapman v. United States, 500 U.S. 453, 468 (1991) (holding that "the weight of the carrier medium must be included").

97 Neal, 516 U.S. at 295. 
of LSD on any carrier medium would automatically be given a presumed weight of 0.4 milligrams. ${ }^{98}$ Citing to the first two cases in the trilogy, the Neal Court unanimously held that the Commission's interpretation was invalid because it could not be squared with the Court's prior holding in Chapman that actual weight be used:

In these circumstances, we need not decide what, if any, deference is owed the Commission in order to reject its ... interpretation. Once we have determined a statute's meaning, we adhere to our ruling under the doctrine of stare decisis, and we assess an agency's later interpretation of the statute against that settled law. ${ }^{99}$

Essentially, this trilogy of decisions ending with Neal provides that when the Court has independently interpreted a term on a prior occasion, that interpretation becomes "incorporated" into the statute and binds the executive branch. ${ }^{100}$ Therefore, the ambiguity that existed with regard to the statutory language at issue is settled, leaving no "space, so to speak, for the exercise of continuing agency discretion."'101

Because Chevron limited the ability of a court to interpret a statutory term independently, this "incorporation rule" 102 generally will apply only in two distinct contexts. The first instance is where the judicial interpretation was made in the pre-Chevron era under the independent judgment model, rather than the deferential model. ${ }^{103}$ The second instance is where the judicial

98 Id. at 287.

${ }^{99}$ Id . at 295 . It is important to emphasize that the Neal Court decided that actual weight was required to be used not because a contrary interpretation was inconsistent with the statutory text, but rather because the contrary interpretation was inconsistent with its prior interpretation of the statutory text in Chapman. See id. at 294.

100 See Maislin Indus., U.S., Inc. v. Primary Steel, Inc., 497 U.S. 116, 130 (1990) (holding invalid the Interstate Commerce Commission's interpretation because it is inconsistent with the Interstate Commerce Act "as it incorporates" the Court's prior interpretation of the Act); see also White, supra note 19, at 727 ("Judicial interpretations of statutes in essence become part of the statutory scheme, until overruled by the Court or Congress, and are binding on the agency").

101 United States v. Mead Corp., 533 U.S. 218, 247 (2001) (Scalia, J., dissenting).

102 This article uses the term "incorporation rule" to refer to the doctrine described supra in the text accompanying notes 84-92. The term refers to the principle that the Supreme Court's interpretation of a term under the independent judgment model effectively incorporates that interpretation into the underlying statute. This forecloses any reinterpretation of that term by the executive branch, even if such re-interpretation would have been upheld under Chevron had it been issued in the absence of the earlier judicial interpretation.

103 See, e.g., Lechmere, Inc. v. NLRB, 502 U.S. 527, 538 (1992) (holding that a 1955 precedent was controlling); Maislin, 497 U.S. at 131 (holding that a 1915 precedent was controlling); see also Merrill \& Hickman, supra note 40, at 915-20 (discussing the application of the incorporation rule in cases when the judicial interpretation was not made "in full awareness of Chevron and its two-step procedure"). It is important to note that in 
interpretation was made post-Chevron in the absence of a Mead-qualified agency interpretation. ${ }^{104}$ This second instance will occur if the judicial interpretation was made in the absence of any agency position whatsoever, ${ }^{105}$ or if the judicial interpretation was made after considering a non-Meadqualified agency position. ${ }^{106}$ In both instances, the Court will have independently interpreted the statute and that interpretation will trump any later inconsistent agency interpretation. This trumping will occur even if the Court, while independently interpreting the statute, adopts the precise interpretation advocated by the agency after according the position appropriate respect under Skidmore. ${ }^{107}$

Commentators have criticized the incorporation rule, arguing that the rule is inconsistent with the policy justifications underlying Chevron. ${ }^{108}$ While Chevron recognizes that politically accountable agencies should bear primary

these cases, the Court determined that its pre-Chevron interpretations "need not be reconsidered after Chevron in light of agency regulations that were already in force when [the pre-Chevron] decisions were issued." Alexander v. Sandoval, 532 U.S. 275, 281 n.1 (2001). In other words, pre-Chevron Supreme Court interpretations are controlling on the agency, even if they were inconsistent with then-existing agency positions that would have been upheld under Chevron if the case had taken place in the post-Chevron era. Simply put, Chevron does not apply retroactively to Supreme Court cases that were decided prior to Chevron.

104 See, e.g., Neal, 516 U.S. at 295-96 (holding that a 1991 precedent was controlling); see also Bamberger, supra note 18, at 1298-99 (discussing the application of the incorporation rule where the judicial interpretation was made in the absence of a Meadqualified interpretation). Bamberger also notes that the incorporation rule could be implicated in one other context: where a post-Chevron independent judicial interpretation is made because a Mead-qualified agency interpretation is nonetheless struck down under Chevron step two. Id at 1298 . This will rarely, if ever, occur, however, because Chevron step two failures rarely, if ever, occur. See Levin, supra note 37, at 1261 (stating that as of 1997, "the [Supreme] Court has never once struck down an agency's interpretation, by relying squarely on the second Chevron step").

${ }^{105} \mathrm{See}$, e.g., Neal, 516 U.S. at 289 (involving a prior interpretation rendered in the absence of an agency position on the matter).

106 See Mead Corp., 533 U.S. at 249-50 (Scalia, J., dissenting) ("What a court says is the law after according Skidmore deference will be the law forever, beyond the power of the agency to change even through rulemaking."); see also Bamberger, supra note 18, at 130001 (describing the application of the incorporation rule where the post-Chevron judicial interpretation was rendered after giving Skidmore respect to an agency position).

107 See Mead Corp., 533 U.S. at 249-50 (Scalia, J., dissenting).

108 See Merrill, supra note 16, at 989 (observing that "if a court has construed an ambiguous statute one way (without the benefit of an agency view), and an agency later has occasion to read the statute differently, the logic of Chevron would seem to indicate that the court should follow the agency interpretation, rather than the earlier judicial pronouncement"); see also Bamberger, supra note 18, at 1302 (suggesting that the incorporation rule "frustrates the very policy justifications for the administrative state articulated by the Supreme Court"). 
interpretive responsibility with regard to ambiguous statutory language, the incorporation rule, to the extent it applies, transfers this responsibility to the politically-insulated judiciary. ${ }^{109}$ Furthermore, because the incorporation rule locks in the Court's interpretation pursuant to the doctrine of stare decisis, the rule restricts the flexibility of agencies to amend the interpretation of an ambiguous statute to reflect current political preferences and adapt to current realities. ${ }^{10}$

In addition, the incorporation rule results in wholly bizarre and unfortunate practical consequences. Under the rule, if litigation involving an ambiguous statute arrives at the Court prior to an agency rendering a Mead-qualified interpretation, the Court will interpret the term independently, and its interpretation will control forever, unless and until Congress amends the statute or the Court takes the highly unusual step of overruling its precedent. ${ }^{111}$ Alternatively, if an agency renders a Mead-qualified interpretation before the Court hears the case, the agency will forever bear primary interpretive responsibility with regard to the statute, allowing the agency to change its mind subject only to Chevron step two. ${ }^{112}$ As a result, the practical import of the incorporation rule is that "the timing of judicial challenges becomes a significant factor in determining policy; vagaries replace values." 113

109 See Bamberger, supra note 18, at 1295 (arguing that the incorporation rule undermines Chevron in that, while "Chevron places the discretion to construe statutory ambiguity outside the judicial ambit, the incorporation conception of precedent brings policymaking within it").

110 Mead Corp., 533 U.S. at 247 (Scalia, J., dissenting) (maintaining that, unlike a judicial determination that an agency interpretation is permissible under Chevron, a judicial interpretation rendered without the benefit of a $\mathrm{Mead}$-qualified interpretation "does not ... leave the matter within the control of the Executive Branch for the future").

111 See supra text accompanying notes 93-107.

112 See supra text accompanying notes $56-60$.

113 Bamberger, supra note 18, at 1304. In addition, in cases in which the agency interpretation prevails, the incorporation rule places great importance as the basis for such victory. For instance, if the agency position prevails because it was permissible under Chevron step two, then a later reasonable, though inconsistent, position would be upheld. See supra text accompanying notes 56-60. If, however, the agency position prevails because it was the result of an independent judicial determination after giving the position appropriate respect under Skidmore, then a later inconsistent though reasonable position would be struck down. See supra text accompanying notes 80-86. The majority in Edelman v. Lynchburg College, 535 U.S. 106 (2002), did not appreciate the effect of this subtle yet significant distinction. In that case, the majority upheld an EEOC regulation's interpretation without specifying the rationale for its decision. The Court found that "the EEOC rule [was] not only a reasonable one, but the position [it] would adopt even if there were no formal rule and [the Court was] interpreting the statute from scratch." $I d$. at 114. The Court further stated that "because [it] so clearly agree[d] with the EEOC, there [was] no occasion to defer and no point in asking what kind of deference, or how much." Id. Accompanying this last sentence was a footnote clarifying that the Court was not holding "that the EEOC's position is the "only one permissible," implying that the EEOC was free to change its position 
Even worse, this nonsensical result, which could never be desired by any rational legislator, ${ }^{114}$ is actually the product of two doctrines that are based on imputed legislative intent. As previously discussed, the Chevron doctrine is based on the notion that Congress generally wants politically accountable agencies to reconcile gaps and ambiguities, ${ }^{115}$ while the Court's reluctance to overturn its statutory interpretation precedents is based on the notion that any Supreme Court interpretation left unchanged by Congress reflects Congress's intention. ${ }^{116}$ While these factual inferences are questionable, they are at least facially plausible; however, the effect of their interaction (i.e., the importance placed on the timing of judicial challenges) is preposterous.

This emphasis on timing creates unfortunate incentives for both agencies and the Supreme Court. It creates the incentive for agencies to hastily draft ambiguous Mead-qualified interpretations (such as notice-and-comment regulations) in order to beat the Supreme Court to the punch and retain "jurisdiction" over the statutory ambiguities.117 These agencies could thereafter issue less formal guidance clarifying the ambiguous Mead-qualified interpretations. Because the Court gives Chevron-like deference to agency interpretations of their own regulations, ${ }^{118}$ this method would be a successful

subject only to Chevron step two. Id. at 114 n.8. As Justice O'Connor noted in her concurring opinion, however, this footnote's implication (that the agency retained flexibility) is only true if the Court's conclusion was based on Chevron deference. Id. at 122 (O'Connor, J., concurring). Otherwise, the Court was independently interpreting the statute, and such interpretation would necessarily foreclose any future inconsistent interpretation. Id. Therefore, there was a "point in asking what kind of deference" was afforded the EEOC position-namely, to give guidance to the EEOC regarding the validity of a later, inconsistent interpretation. Id. at 114 (Souter, J.).

114 This silliness is clear when you consider the potential responses to the following hypothetical question posed to a legislator drafting new legislation: "Who do you want to have primary interpretive responsibility with regard to ambiguities and gaps in the new statute?" The response that "it depends on whether a controversy arrives at the Supreme Court before the agency issues a Mead-qualified interpretation" is completely implausible.

115 See supra text accompanying notes 43-47.

116 See supra text accompanying notes 76-77.

117 See Bamberger, supra note 18, at 1302-03.

118 See United States v. Cleveland Indians Baseball Co., 532 U.S. 200, 220 (2001) (holding that an agency's reasonable interpretation of its own regulations is entitled to substantial judicial deference); Auer v. Robbins, 519 U.S. 452, 461 (1997) (finding that a court should defer to an agency's construction of its regulations unless it is "plainly erroneous or inconsistent with the regulation" (quoting Bowles v. Seminole Rock \& Sand Co., 325 U.S. 410, 414 (1945))); Merrill \& Hickman, supra note 40, at 899 (identifying "a substantial parallel between the Chevron doctrine and the Seminole Rock doctrine"). The Seminole Rock doctrine has been criticized on various grounds. See John F. Manning, Constitutional Structure and Judicial Deference to Agency Interpretations of Agency Rules, 96 COLUM. L. REV. 612, 686-90 (1996) (criticizing the Seminole Rock doctrine because it is inconsistent with contemporary separation of powers principles, and suggesting the doctrine does not give agencies an adequate incentive to draft clear regulations). 
end run around the incorporation rule. Unfortunately, this end run results in greater ambiguity and less deliberation with respect to formal guidance and the proliferation of informal guidance. ${ }^{119}$

With respect to the Supreme Court, the importance of timing creates improper incentives with regard to its case management. For instance, if the Court embraces Chevron and its underlying principles, it will want to refrain from granting certiorari in statutory interpretation cases where the agency charged with administering the statute has not yet rendered a Mead-qualified interpretation. By refusing to hear these cases, the Court leaves "a space, so to speak, for the exercise of continuing agency discretion," 120 giving the agency the opportunity to interpret the term in a Mead-qualified manner and thus retain primary interpretative authority. Had the Court accepted the case, it would be forced to interpret the term independently, thereby locking in the interpretation under stare decisis. ${ }^{121}$

119 The Mead decision, granting Chevron deference to only relatively formal agency action, has itself been criticized for creating incentives for agencies to "rush out barebones, ambiguous rules construing statutory ambiguities, which they can then in turn further clarify through informal rulings entitled to judicial respect." United States v. Mead Corp., 533 U.S. 218,246 (2001) (Scalia, J., dissenting). For this strategy to be successful, the incorporation rule requires the Mead-qualified rule to be promulgated prior to a Supreme Court interpretation of the statute in question. Otherwise, the Supreme Court's interpretation will be binding.

${ }^{120}$ Id. at 247. A pro-Chevron Court would be especially hesitant to take a case in which the agency had issued a regulation that, because it lacked retroactive effect, would not apply in that case. For example, assume that the case involved a tax issue that arose in 2000 when there was no Mead-qualified interpretation on point. In 2001, the Treasury promulgates a Mead-qualified regulation that resolved the issue; however, the regulation (like most tax regulations) lacked retroactive effect. See I.R.C. $\$ 7805$ (b) (2000) (stating the general rule that tax regulations are not retroactive). The Supreme Court, if it granted certiorari, would independently interpret the term (without the benefit of the regulation because it would not apply to the taxpayer's case), thereby locking in the judicial definition whether it was consistent or inconsistent with the Treasury regulation. By denying certiorari, however, the Treasury regulation would control going forward, and the Treasury would retain the flexibility to change the regulation subject only to Chevron step two.

121 See supra text accompanying notes 80-82. Kenneth Bamberger has recently noted that a pro-Chevron Court might revitalize the "primary jurisdiction" doctrine in an attempt to leave the ambiguous statutory term within the jurisdiction of the agency. Bamberger, supra note 18, at 1309-10. Under this doctrine, which Bamberger notes has not been applied by the Court since Chevron, the Court would refer "specific issues of the type usually resolved in agency adjudication" back to the agency prior to resolution of the case by the Court. Id. at 1309 . Bamberger ultimately concludes that the use of this doctrine to avoid the problems caused by the incorporation rule would itself raise significant problems such as increased costs and delay. Id. In the tax context, the primary jurisdiction doctrine would be unworkable because the Mead-qualified interpretations of the Treasury (i.e., regulations) generally cannot have retroactive effect. See I.R.C. $\S 7805$ (b). Therefore, any Treasury regulations promulgated after a referral by the Court under the "primary 
Alternatively, if the Court is hostile to Chevron and its principles, the emphasis on timing will create an incentive for the Court to accept statutory interpretation cases lacking a Mead-qualified interpretation. Such a Court would be aggressive in seeking out these cases so that it could lock in a judicial interpretation, thereby taking away agency discretion. As a result, the Court would shift power from the executive branch to the judiciary. Accordingly, regardless of the disposition of the Court towards Chevron, the "race" to interpret creates a case management incentive that is entirely unrelated to the merits of the petition for certiorari.

In summary, the incorporation rule undermines the principles behind Chevron and places tremendous importance on the timing of judicial challenges. This emphasis on timing in turn creates improper incentives for both agencies and the Supreme Court in their "race" to interpret ambiguous statutes. Nonetheless, the incorporation rule persists. In fact, it is so entrenched that the Court has recently concluded that it is a "settled principle." 122

\section{E. Chevron's Applicability to Tax Regulations}

\section{Pre-Chevron Law}

Prior to Chevron, tax law had a relatively well-developed body of law regarding the standard of judicial review of Treasury regulations interpreting ambiguous tax statutes. ${ }^{123}$ The standard depended on whether the regulation was issued pursuant to authority granted in a specific Code provision (a specific authority regulation), ${ }^{124}$ or whether the regulation was issued pursuant to the general grant of authority contained in $\S 7805$ (a) (a general authority regulation). ${ }^{125}$

The traditional view was that specific authority regulations ${ }^{126}$ were

jurisdiction" doctrine would be issued too late to have any relevance to the taxpayer's case.

122 Alexander v. Sandoval, 532 U.S. 275, 281 n.1 (2001).

123 See Merrill \& Hickman, supra note 40, at 838 (mentioning that tax had "substantial bodies of precedent [about deference] that preexisted Chevron and deviated from it in important respects"); see also Coverdale, supra note 62, at 72-76 (discussing traditional tax deference doctrine with regard to Treasury regulations).

${ }^{124}$ See, e.g., I.R.C. $\S 121(\mathrm{c})(2)(\mathrm{B})$ (authorizing Treasury to promulgate regulations defining the term "unforeseen circumstances" for purposes of determining whether the gain from the sale of principal residence may be excluded from gross income). There are over one-thousand of these specific authority grants in the Code. See Edward J. Schnee \& W. Eugene Seago, Deference Issues in the Tax Law: Mead Clarifies the Chevron Rule-Or Does It?, 96 J. TAX'N 366, 371 (2002) (counting approximately 1220 delegations of authority in the Code).

${ }^{125}$ I.R.C. $\S 7805(a)$ authorizes the Treasury to "prescribe all needful rules and regulations for the enforcement of [the Internal Revenue Code]." I.R.C. $\S 7805$ (a) (2000).

${ }^{126}$ Tax lawyers generally refer to these regulations as "legislative regulations" and general authority regulations as "interpretive regulations." Coverdale, supra note 62, at 65- 
controlling unless they were determined to be arbitrary, capricious, or manifestly contrary to the will of Congress. ${ }^{127}$ Although it appears that this standard is merely the product of merging Chevron's two steps into one, ${ }^{128}$ it has been argued that the historical deference afforded specific authority regulations might actually be greater than that afforded under Chevron. ${ }^{129}$

With regard to general authority regulations, they would be upheld if they were reasonable implementations of congressional directives. ${ }^{130}$ In determining reasonableness, a court would focus on "whether the regulation harmonizes with the plain language of the statute, its origin, and its purpose."131 Pursuant to this analysis, a court could consider a number of factors, including "the length of time the regulation has been in effect, the reliance placed on it, the

66. I refrain from using these terms because administrative law draws distinctions between these terms in a vastly different way. See Thomas W. Merrill \& Kathryn Tongue Watts, Agency Rules with the Force of Law: The Original Convention, 116 HARV. L. REV. 467, 476-77 (2002) (defining legislative regulations as "those that have the force and effect of law [such that] [f]rom the perspective of agency personnel, regulated parties, and courts, these rules have a status akin to that of a statute" and interpretive regulations as all other regulations). Therefore, in areas of the law other than tax, a regulation may be deemed legislative regardless of whether it was promulgated pursuant to a general grant of authority. See id. at 570 (explaining that unlike the FTC, FDA, and NLRB, the IRS "continues to adhere to the notion that the ... general rulemaking grant in section 7805 (a) . . confers only interpretive, not legislative, rulemaking authority"). Because of the inconsistent use of these terms, and because administrative law places great importance on the characterization of a regulation as legislative or interpretive (as those terms are used for administrative law purposes), see id. at 477-81, I will use the terms "specific authority" and "general authority" rather than "legislative" and "interpretive."

127 See Coverdale, supra note 62, at 73-74 (describing the pre-Chevron standard with respect to specific authority regulations).

128 With regard to specific authority regulations, Congress has specifically delegated policy-making authority to the Treasury. See supra note 124 and accompanying text. Therefore, under a Chevron standard, these regulations would almost inevitably pass step one, since Congress has explicitly left a gap for the Treasury to fill. See Chevron U.S.A., Inc. v. Natural Res. Def. Council, Inc., 467 U.S. 837, 842 (1984). As a result, one would usually move directly to step two, which appears to operate much like the traditional standard. See id. at 843.

129 See John F. Coverdale, Court Review of Tax Regulations and Revenue Rulings in the Chevron Era, 64 GEO. WASH. L. REV. 35, 54-55 (1995) (suggesting that, because the historical deference standard gave weight to Treasury's view even at step one of the analysis, the historical standard may be even more deferential than Chevron). Coverdale acknowledges that this distinction will not likely matter with regard to specific authority regulations where Congress has intentionally left a gap for Treasury to fill since it is "unlikely [in those instances] that a court would be able to find that Congress had directly addressed the precise issue raised." Id.

${ }^{130}$ Nat'l Muffler Dealers Ass'n v. United States, 440 U.S. 472, 476-77 (1979); see also Ellen P. Aprill, Muffled Chevron: Judicial Review of Tax Regulations, 3 FLA. TAX REv. 51, 57-61 (1996) (examining the pre-Chevron range of judicial deference).

131 Nat'l Muffler Dealers Ass'n., 440 U.S. at 477. 
consistency of the Commissioner's interpretation, and the degree of scrutiny Congress has devoted to the regulation during subsequent re-enactments of the statute." 132

This multi-factor standard differs from Chevron's two step analysis. ${ }^{133}$ Many of the factors seem to have little or no significance under Chevron, although some might be relevant under Chevron step two. ${ }^{134}$ Despite this difference, it is unclear to what extent, if any, the multi-factor test produced outcomes different than that which would have resulted under Chevron. ${ }^{135}$

\section{Does Chevron Apply to Tax Law?}

In the decade or so after Chevron, it was unclear to what extent, if any, this well-developed deference law was displaced by Chevron. ${ }^{136}$ During this period, courts reviewing tax regulations sometimes used the traditional standard of review and other times used the Chevron standard. Professor John Coverdale has attributed this failure to apply Chevron consistently to "the sociology' of the tax bar and bench." 137 Coverdale explains, "The tax bar is highly specialized, and its members rarely litigate cases that challenge non-tax regulations. Senior tax lawyers in the private sector, in the IRS or on the bench of the Tax Court may, therefore, simply be unaware of Chevron."138 Eventually, however, the tide turned and the courts began to apply the Chevron methodology to tax cases on a consistent basis. ${ }^{139}$

132 Id.

133 For a discussion of the multi-factor standard and its relationship to Chevron in tax cases, see generally Aprill, supra note 130.

${ }^{134}$ For example, if an agency changes a long-standing interpretation that has been frequently relied upon, a court might require a very thoughtful deliberation by the agency before accepting the new interpretation under Chevron step two. See Pierce, supra note 41, at 2252-53 (emphasizing the significance the Court places on the decisionmaking process when applying Chevron step two to changes in agency precedent).

135 See Aprill, supra note 130 at 58-59, 63-73 (discussing and comparing multi-factor and Chevron standards).

${ }^{136}$ See Coverdale, supra note 129, at 53-57 (concluding that between 1984 and 1995, out of the more than fifty cases analyzing the validity of specific authority regulations, only fourteen cited Chevron, and that as of 1995, "[c]ourts rarely apply Chevron's two-step mode of analysis to general authority regulations"). But see David A. Brennen, Treasury Regulations and Judicial Deference in the Post-Chevron Era, 13 GA. ST. U. L. REV. 387, 417 (1997) (suggesting that the decisions in Coverdale's sample were consistent with the outcomes that would have resulted under Chevron's methodology).

137 Coverdale, supra note 129 , at 53 n. 121 .

$138 \mathrm{Id}$.

139 See, e.g., Atl. Mut. Ins. Co. v. Comm'r, 523 U.S. 382, 387 (1998); Conn. Gen. Life Ins. Co. v. Comm'r, 177 F.3d 136, 143-45 (3d Cir. 1999); Bankers Life \& Cas. Co. v. United States, 142 F.3d 973, 983-84 (7th Cir. 1998); ABC Rentals of San Antonio, Inc. v. Comm'r, 142 F.3d 1200, 1207 (10th Cir. 1998); Redlark v. Comm'r, 141 F.3d 936, 939-40 (9th Cir. 1998); Harbor Bancorp \& Subsidiaries v. Comm'r, 115 F.3d 722, 727 (9th Cir. 


\section{Are General Authority Regulations Mead-Qualified?}

Under Mead, Chevron deference clearly applies to specific authority regulations where Congress has specifically delegated gap-filling authority for the Treasury to implement through regulation. ${ }^{140}$ The question that remains is whether Chevron deference or, alternatively, Skidmore respect, applies to general authority regulations. ${ }^{141}$

General authority regulations would qualify for Chevron deference if "it [was] apparent from the [Treasury's] generally conferred authority and other statutory circumstances that Congress would expect" that these regulations would carry "the force of law."142 Although the resolution of this issue is not entirely clear, ${ }^{143}$ the courts, in the few cases that have addressed the issue since

1997); Tate \& Lyle, Inc. v. Comm'r, 87 F.3d 99, 104-06 (3d Cir. 1996); Peoples Fed. Sav. \& Loan Ass'n of Sidney v. Comm'r, 948 F.2d 289, 299 (6th Cir. 1991); Robinson v. Comm'r, 119 T.C. 44,68 (2002) (each citing Chevron while analyzing the validity of a Treasury regulation). Accord PIERCE, supra note 16, $\S 3.5$ at 167-68 (concluding that Chevron applies to tax regulations); Coverdale, supra note 62, at 77 (concluding that "as the years went by [the courts have] turned somewhat more frequently to Chevron" when analyzing the validity of specific authority regulations). The Supreme Court has never made it entirely clear that Chevron displaced traditional notions of tax deference. For example, in Atlantic Mutual Insurance Co. v. Commissioner, the Court cited Chevron with regard to step one of its analysis but then curiously cited Cottage Savings Ass' $n$ v. Commissioner, 499 U.S. 554, 560-61 (1991), rather than Chevron for its step two analysis. Atl. Mut. Ins. Co., 523 U.S. at 387, 389. More recently, in Boeing Co. v. United States, even though the Court failed to cite Chevron in analyzing the validity of a general authority regulation, it applied a very Chevron-like analysis, concluding that the regulation was entitled to "deference" and upholding the regulation because it was "not arbitrary." 537 U.S. 437, 449, 451 (2003).

140 United States v. Mead Corp., 533 U.S. 218, 229 (2001).

141 Recall that this distinction affects not only the quantity of respect given to the regulation, but also the quality of the judicial action necessitated by a review of the regulation. If Chevron deference applies, the court will not independently interpret the term; if Skidmore respect applies, the court will independently interpret the term and stare decisis will be triggered with regard to such interpretation. See supra text accompanying notes 77-83.

142 Mead Corp., 533 U.S. at 229.

143 Chevron itself involved an environmental regulation promulgated pursuant to the EPA's general grant of authority to prescribe such regulations as necessary, see 42 U.S.C. $\S$ 7601 (a)(1), suggesting that the Treasury's general authority regulations should likewise merit Chevron deference. If Treasury's only mechanism for making policy was through the promulgation of regulations that were specifically authorized by Congress, it would undermine the Chevron notion that Congress implicitly leaves policy-making authority to the agency (rather than the courts) when it leaves ambiguities and gaps within its statutes. See Chevron U.S.A., Inc. v. Natural Res. Def. Council, Inc., 467 U.S. 837, 843-44 (1984). Furthermore, Treasury's general authority regulations are promulgated after notice and comment, a procedural formality emphasized by the Mead Court as indicative of force-oflaw interpretations. See Mead Corp., 533 U.S. at 230-31. Additionally, a general authority regulation is a rule of general applicability rather than an agency action that is limited in its 
Mead, appear to be giving Chevron deference to these regulations. ${ }^{144}$ Because this article argues that the check-the-box regulations, which were issued pursuant to Treasury's general authority, ${ }^{145}$ are invalid, it is assumed below

operation, another factor considered by the Mead Court. See id. at 233-34.

Some commentators have argued, however, that general authority regulations do not merit Chevron deference. See Coverdale, supra note 62, at 83-89; Schnee \& Seago, supra note 124 , at 369-70. They note that Treasury, by deciding that these regulations do not require notice and comment, essentially admits that they lack the "force of law." Coverdale, supra note 62 , at $84-85$. Although Treasury takes the position that notice and comment is not required, it regularly submits to notice and comment on a voluntary basis. MiCHAEL J. SAltZMan, IRS PRACTICE AND PROCEDURE $\S 3.02[3]$, at 3-6 (2d ed. 1991). Furthermore, these commentators believe that Congress's frequent use of specific authority in the Code suggests that Congress does not desire that Treasury act with the force of law when it promulgates general authority regulations. Coverdale, supra note 62 , at 85 . In addition, the commentators argue that the historical tax deference doctrine, which treated general authority regulations with less respect than specific authority regulations, should be understood as a backdrop against which Congress legislated. Id. at 86-87. According to this argument, by giving specific authority in the Code, Congress signals its desire to have the courts defer to the Treasury's position; by failing to give such specific authority, Congress signals its desire to have the courts give greater scrutiny to the Treasury's position. Id. Finally, the commentators point to pervasive congressional involvement in tax law, evidencing "Congress's strong preference for making policy choices itself rather than leaving them to the Treasury." Id. at 87.

144 See, e.g., Marsh \& McLennan Cos. v. United States, 302 F.3d 1369, 1375 (Fed. Cir. 2002) (citing Mead in applying Chevron to a general authority regulation without discussing the distinction between general authority and specific authority regulations); Tax Analysts $v$. I.R.S., 215 F. Supp. 2d 192, 198 (D.D.C. 2002) (citing Mead for the proposition that Chevron applies to general authority regulation because the regulation was "enacted . . . in a formal rulemaking process"); Robinson v. Comm'r, 119 T.C. 44, 68-70 (2002) (applying Chevron to a temporary general authority regulation post-Mead without citing or discussing Mead); see also U.S. Freightways Corp. v. Comm'r, 270 F.3d 1137, 1141 (7th Cir. 2001); Landmark Legal Found. v. I.R.S., 267 F.3d 1132, 1135-36 (D.C. Cir. 2001); Am. Express Co. v. United States, 262 F.3d 1376, 1382 (Fed. Cir. 2001); Schlumberger Tech. Corp. v. United States, 55 Fed. Cl. 203, 212-13 n.5 (2003) (each suggesting in dicta that Mead mandates giving Chevron deference to all regulations promulgated with full notice and comment); Mitchell M. Gans, Deference and the End of Tax Practice, 36 REAL Prop. ProB. \& TR. J. 731, 750 (2002) (concluding that after Mead, it is "clear that Chevron's framework is applicable to [general authority] regulations"). But see Robinson, 119 T.C. at 119-20 (Vasquez, J., dissenting); Coverdale, supra note 62, at 83-89; Schnee \& Seago, supra note 124, at 369 (arguing that general authority regulations do not qualify for Chevron deference under Mead). As noted in note 139, supra, in Boeing Co. v. United States, the Court recently upheld a general authority regulation, reasoning that it merited "deference" and was "not arbitrary." 537 U.S. 437, 448-49 (2003). Curiously, even though the Court applied a very Chevron-like analysis by deferring to a non-arbitrary agency position, it cited neither Mead nor Chevron.

145 See Simplification of Entity Classification Rules, 61 Fed. Reg. 66,584 (Dec. 18, 1996) (to be codified at 26 C.F.R. pts. 1, 301, 602) (codifying regulations that classify business 
that they qualify for the highly deferential Chevron standard of review. However, the analysis would be equally applicable even if they qualified only for respect under Skidmore.

\section{THE HISTORICAL DEFINITION OF "ASSOCIATION": FROM MORRISEY TO CHECK-THE-BOX}

The check-the-box regulations govern the classification of unincorporated business entities as corporations or partnerships for federal income tax purposes. ${ }^{146}$ This classification is critical, primarily because the earnings of a corporation are generally subject to two levels of tax, while the earnings of a partnership are subject only to one.

When a corporation earns income, a corporate income tax is imposed on the corporation with respect to that income. ${ }^{147}$ When the corporation then distributes its after-tax earnings to its shareholders, an individual income tax is imposed on the shareholders with respect to the distribution. ${ }^{148}$ On the other hand, when a partnership earns income, only its shareholders are taxed on their share of the income, ${ }^{149}$ and there is no additional tax imposed when the partnership then distributes the income to its partners. ${ }^{150}$ In other words, the income of a partnership flows through the partnership to its partners and is reported on the partners' individual tax returns.

In general, every business entity is classified as either a corporation or a partnership for tax purposes. ${ }^{151}$ In classifying a business entity, one first looks to the definition of "corporation" in $\S 7701$ (a)(3). Any business entity that falls outside this definition is classified by default as a partnership pursuant to $\S 7701(\mathrm{a})(2)$.

Since 1918, $\S 7701(a)(3)$ and its predecessors have defined the term corporation as follows: "The term 'corporation' includes associations, jointstock companies, and insurance companies." 152 As a result, the Code imposes

organizations under an elective regime).

146 Treas. Reg. $\S 301.7701-1$ to -3 (as amended in 2002).

147 I.R.C. $\S 11$ (2000). Certain corporations are subject to unique taxing regimes. See supra note 3.

148 See I.R.C. $\$ \S 61(\mathrm{a})(7), 301(\mathrm{c})(1), 316$ (2000) (providing that dividends are included in gross income and defining the term dividend as corporate distributions out of earnings and profits).

149 See I.R.C. $\$ \S 701,702(2000)$ (providing that partners, and not the partnership itself, are taxed on partnership income and that partners are taxed on their distributive shares of partnership income, respectively).

${ }^{150}$ I.R.C. $\$ 705(\mathrm{a})(1)(\mathrm{A})(2000)$.

151 Treas. Reg. $\S 301.7701-2$ (a) (as amended in 2002). Business entities with a single owner are classified either as a corporation or as an entity that is disregarded for tax purposes. Treas. Reg. $\S 301.7701-3$ (a) (as amended in 2002). For simplicity purposes, I assume that all business entities discussed below have at least two owners.

${ }^{152}$ I.R.C. $\S 7701$ (a)(3). See also Revenue Act of 1918, ch. 18, § 1. As far back as 1894, 
an income tax not only on state-law corporations, but also on associations. ${ }^{153}$ During the infancy of the income tax, the definition of the term "association" baffled courts and administrators. ${ }^{154}$ In 1935, the Supreme Court in Morrissey v. Commissioner ${ }^{155}$ finally provided some definitive guidance as to the meaning of "association."

\section{A. Morrissey v. Commissioner}

In Morrissey, the question was whether, during the taxable years of 1924 through 1926, a trust was taxable as a corporation, which in turn depended on whether the trust constituted an association. ${ }^{156}$ Pursuant to the trust instrument, the trustees were authorized to acquire, construct, and operate golf courses. ${ }^{157}$ The trust also provided that the beneficiaries would not be personally responsible for the trust's debts. ${ }^{158}$ The beneficial interests of the trust were evidenced by transferable certificates similar to stock certificates issued by corporations. ${ }^{159}$ All of the decisions with respect to the trust corpus would be made by the trustees, and the beneficiaries had no power to elect or remove trustees. ${ }^{160}$ The term of the trust was twenty-five years, notwithstanding the death of any trustee or beneficiary. ${ }^{161}$

The trust's position that it was not an association was based on Regulation 45 , which was promulgated in $1921^{162}$ and superceded by the issuance of Regulation 65 in 1924. ${ }^{163}$ Regulation 45 provided that a trust would constitute an association only if the beneficiaries "have a voice in the conduct of the business of the trust, whether through the right periodically to elect trustees or

the tax laws used the term "association" interchangeably with "corporation." See Revenue Act of 1894 , ch. $349, \S 32$ (applying tax on "corporations, companies, or associations"); Revenue Act of 1909 , ch. $6, \S 38$ (applying tax on "every corporation, joint stock company, or association"); Revenue Act of 1913, ch. 16, $\S$ IIG(a) (applying tax on the net income of "every corporation, joint-stock company or association"); Revenue Act of 1916, ch. 463, $\S$ 10 (taxing "every corporation, joint-stock companies or association").

153 See I.R.C. $\S 11(a)$ (2000) (imposing a tax on the taxable income of every corporation).

154 See Coleman-Gilbert Assocs. v. Comm'r, 76 F.2d 191, 193 (1st Cir. 1935) (describing the law dealing with the definition of association as being "in a hopeless state of confusion").

155296 U.S. 344 (1935).

156 Id. at 347.

$157 \mathrm{Id}$.

158 Id.

159 Id.

${ }^{160} \mathrm{Id}$. The trustees could voluntarily hold meetings "for the purpose of making reports or considering recommendations, but the votes of the [beneficiaries] were to be advisory only." Id.

${ }^{161}$ Id. at $347-48$.

162 Treas. Reg. 45, art. 1504, T.D. 3146, 23 Treas. Dec. Int. Rev. 352, 591 (1921).

163 Treas. Reg. 65, art. 1504, T.D. 3640, 26 Treas. Dec. Int. Rev. 745, 1003 (1924). 
otherwise."164 Thus, Regulation 45 announced a control test: only if the beneficiaries had some control over the corpus of the trust would the trust be considered an association. ${ }^{165}$

In Regulation 65, Treasury discarded the control test, deciding that the key issue was whether the trust was "carrying on some business enterprise."166 Under this business enterprise test, a trust that engaged in any business activity would be considered an association, regardless of the level of beneficiary control. ${ }^{167}$

The trust in Morrissey argued that, since the beneficiaries had no control over the trust corpus, the trust was not an association under Regulation 45. ${ }^{168}$ The trust argued that Regulation 65 , which ordinarily would apply to the taxable years in question, was invalid because the standard set forth in Regulation 45 was effectively "incorporated" into the statute by virtue of the intervening congressional enactment of the Revenue Act of 1924, which reenacted the definition of corporation as including associations. ${ }^{169}$ The Court disposed of this argument in a manner that foreshadowed Chevron:

As the statute merely provided that the term "corporation" should include "associations," without further definition, the Treasury Department was authorized to supply rules for the enforcement of the Act within the permissible bounds of administrative construction. Nor can this authority be deemed to be so restricted that the regulations, once issued, could not later be clarified or enlarged so as meet administrative exigencies or conform to judicial decision. We find no ground for the contention that by the enactment of the Revenue Act of 1924 the Department was limited to its previous regulations as to associations. ${ }^{170}$

In finding an ambiguity in the statute, the Morrissey Court recognized a "space, so to speak, for the exercise of continuing agency discretion."171 As a result, the Court determined that the agency could change its mind with respect to the interpretation of the term association, notwithstanding an intervening reenactment of the underlying statute.

164 Treas. Reg. 45, art. 1504, T.D. 3146, 23 Treas. Dec. Int. Rev. at 591.

165 Id.

166 Treas. Reg. 65, art. 1504, T.D. 3640, 26 Treas. Dec. Int. Rev. at 1003.

167 Id. The regulation contrasted trusts that carry on some business enterprise with "[h]olding trusts, in which the trustees [were] merely holding property for the collection of the income and its distribution among the beneficiaries." Id. (holding trusts would not constitute associations).

168 Morrissey v. Comm'r, 296 U.S. 344, 348-49 (1935).

169 Brief for the Petitioner at 30-35, Morrissey (No. 17). The Revenue Act of 1924 was enacted on June 2, 1924, see Revenue Act of 1924, ch. 234, 43 Stat. 253, between the promulgation of Regulation 45 in 1921, see 23 Treas. Dec. Int. Rev. 625, and the promulgation of Regulation 65 on October 6, 1924, see 26 Treas. Dec. Int. Rev. 1049.

170296 U.S. at 354-55 (citation omitted).

171 United States v. Mead Corp., 533 U.S. 218, 247 (2001) (Scalia, J., dissenting). 
Even though the Court dismissed the trust's arguments in a Chevron-like manner, the similarities end there. The government argued that the standard set forth in Regulation 65, that all business trusts constituted associations, should control. ${ }^{172}$ Had the case arisen post-Chevron, the Court's task would have been merely to determine whether the Treasury's Mead-qualified position in Regulation 65 was permissible under step two, ${ }^{173}$ as the Court had already found the term in question to be ambiguous. ${ }^{174}$ Because the regulation would likely have passed this deferential standard, the Court would then have applied the regulation and concluded that the trust was an association because it conducted a business enterprise. ${ }^{175}$

Instead of merely deferring to the regulation's business enterprise test, however, the Morrissey Court did exactly what Chevron now proscribes. ${ }^{176}$ Applying the independent judgment model, the Court exalted its own view over the judgment of the Treasury. ${ }^{177}$ After "a further examination of the congressional intent," the Court disregarded the regulation and independently

172 Morrissey, 296 U.S. at 349. The Court continued:

The Government insists that the distinction between associations and the trusts [not taxable as associations] is between "business trusts on the one side" and other trusts "which are engaged merely in collecting the income and conserving the property against the day when it is to be distributed to the beneficiaries"; that Congress intended that all "business trusts" should be taxed as associations.

Id.; see also Brief for the Respondent at 6, Morrissey (No. 17) ("We submit that Congress intended that all business trusts should be taxed as associations, and hence that the 'doing business' test which is emphasized by many decisions is the single criterion on which this case should depend.") The government's alternative argument was that a corporate resemblance test should be applied. Id. at 7 ("If it is necessary to have regard for anything more than the activities of the organization and doing business is not the sole test, we think that an organization which does business and enjoys the substantial advantages of centralized control, continuity, and limited liability is an association within the meaning of the statute."). The government preferred the business enterprise test to the corporate resemblance test ultimately adopted by the Court because it believed the latter test was too imprecise. Id. at 20-21.

173 See Chevron U.S.A., Inc. v. Natural Res. Def. Council, Inc., 467 U.S. 837, 842-43 (1984) (setting out the two-step test).

174 See Morrissey, 296 U.S. at 354-55 (pointing out that the statute was not clear enough in defining the rule that associations should be included in the term "corporation").

175 The Court did in fact determine that the trust "involved what was essentially a business enterprise." $I d$. at 360 . Accordingly, under the business enterprise test, the trust would have been characterized as an association.

${ }^{176}$ One might believe that, because Morrissey violates Chevron principles, Morrissey could be overruled on the basis that it is demonstrably erroneous. The Court has determined, however, that it is a "settled principle" that pre-Chevron interpretations "need not be reconsidered after Chevron in light of agency regulations that were already in force when [the pre-Chevron] decisions were issued." Alexander v. Sandoval, 532 U.S. 275, 281 n. 1 (2001).

177 Morrissey, 296 U.S. at 356-57. 
interpreted the term "association" to mean any unincorporated business entity that resembles a corporation. ${ }^{178}$ In applying this corporate resemblance test, the Court identified the following four corporate factors: (1) perpetual existence of the entity notwithstanding the death of owners or their agents, (2) centralization of the entity's management (through, for example, a board of directors or trustees), (3) free transferability of beneficial interests without affecting the continuity of the business entity, and (4) the entity's provision of limited liability for its owners. ${ }^{179}$

In announcing this test, the Court did not identify the weight to be given to each of these factors, appearing to use an overall facts and circumstances test. $^{180}$ Nor did the Court provide any guidance regarding the degree of corporate similarity necessary in order for an entity to be considered an association. ${ }^{181}$

Despite the imprecision of Morrissey's corporate resemblance test, the standard was easy to apply to the trust at issue. The Court found all four corporate factors present and therefore determined that the trust constituted an association. ${ }^{182}$ Notably, this is the same conclusion that would have resulted had the Court merely applied Regulation 65 's business enterprise test. ${ }^{183}$

\section{B. The Kintner Regulations}

Morrissey's imprecise corporate resemblance test remained intact until $1960 .{ }^{184}$ In 1960, the Treasury promulgated regulations, commonly known as the Kintner Regulations, ${ }^{185}$ which provided a more quantifiable standard. ${ }^{186}$ Although the Kintner Regulations cited to Morrissey, ${ }^{187}$ retained its corporate

178 Id.

$179 \mathrm{Id}$. at 359. For an extensive discussion of these factors, see Stephen B. Scallen, Federal Income Taxation of Professional Associations and Corporations, 49 MiNN. L. REV. 603, 631-37 (1965).

${ }^{180}$ Morrissey, 296 U.S. at 358-59; see also Kurzner v. United States, 413 F.2d 97, 104 (5th Cir. 1969) (asserting that Morrissey "gave no indication of the relative weight to be accorded the corporate attributes discussed").

181 See Kurzner, 413 F.2d at 104 (remarking that, although Morrissey emphasized similarity, it "unfortunately did not specify a requisite degree of similarity").

182 Morrissey, 296 U.S. at 360-61.

183 Id. at 353-54

184 See, e.g., United States v. Kintner, 216 F.2d 418, $421-24$ (9th Cir. 1954) (applying the Morrissey standard); Rev. Rul. 57-341, 1957-2 C.B. 884, 886 (1957) (same).

185 See Scallen, supra note 179, at 671 (describing the 1960 regulations as "'Kintner' Regulations"). This name arose from the case United States $v$. Kintner, which held that a professional association constituted a corporation for tax purposes. $216 \mathrm{~F} .2 \mathrm{~d}$ at 428 .

186 See Treas. Reg. $\S 301.7701-1$ to -11 (1960); T.D. 6503, 1960-2 C.B. 409 ("An unincorporated organization shall not be classified as an association unless such organization has more corporate characteristics than noncorporate characteristics.").

187 T.D. $6503,1960-2$ C.B. 409,413 (adopting regulation $\S 301.7701-2(a)(1)$ which cites Morrissey for the proposition that an organization is treated as an association if it 
resemblance standard, ${ }^{188}$ and used its corporate factors, ${ }^{189}$ the regulations provided a mechanical, bright-line test as opposed to Morrissey's vague overall facts and circumstances standard. 190

In particular, the regulations differed from Morrissey in two important ways. First, while Morrissey did not specify the relative weight to be given to each of the four corporate factors, the Kintner Regulations assigned each factor an equal weight. ${ }^{191}$ Second, while Morrissey never explained how much corporate resemblance is required, the regulations provided that, in order for an unincorporated business entity to be classified as an association, the entity would have to possess at least three of the four corporate factors. ${ }^{192}$

Despite the regulations' retention of the corporate resemblance test, it is clear that the regulations were intended to create different substantive results than would occur under Morrissey. The Treasury's motivation in promulgating these regulations was to restrict the ability of professionals to form associations in order to take advantage of pension and profit-sharing benefits then available only to corporations. ${ }^{193}$ This restriction was accomplished by forcing an unincorporated entity to have at least three out of the four corporate factors in order to be classified as an association. ${ }^{194}$

"resembles a corporation" and $\S 301.7701-2(c)(2)$, which cites Morrissey in a discussion of the centralization of management in an organization).

188 See id. (adopting regulation $\S 301.7701-2(a)(1)$, which states that "[a]n organization will be treated as an association if the corporate characteristics are such that the organization more nearly resembles a corporation than a partnership or trust").

189 See id. at 414-17 (adopting regulation $\$ \S 301.7701-2(b)$, discussing continuity of life, $-2(c)$, discussing centralization of management, $-2(d)$, discussing limited liability, and $-2(e)$, discussing free transferability of interests).

190 See id. at 414 (adopting $§ 301.7701-2(\mathrm{a})(3)$ ).

191 See id. at 413-14 (describing four corporate characteristics, and requiring more corporate characteristics than not for an organization to be classified as an association).

192 See id.

193 1 MCKEE ET AL., supra note 1, \ 3.06, at 3-57 (concluding that "there is no question that the proximate inspiration for the 1960 Regulations was to limit the availability of qualified pension benefits by narrowing the substantive scope of the association concept").

194 At the time the Kintner Regulations were promulgated, professionals were generally unable to form corporations under state law. See Patrick E. Hobbs, Entity Classification: The One Hundred-Year Debate, 44 CATH. U. L. REV. 437, 489 (1995). In response to the Kintner Regulations, state legislatures began adopting professional corporation statutes. See $i d$. In turn, the Treasury amended the Kintner Regulations to deny corporate status to professional corporations. T.D. 6797, 1965-1 C.B. 553 ("[A] professional service organization ... would not be classified for purposes of taxation as a "corporation' merely because the organization was so labeled under local law."). This amendment was repeatedly struck down by courts as arbitrary and capricious. See, e.g., Kurzner v. United States, 413 F.2d 97, 112 (5th Cir. 1969). The IRS finally conceded defeat in 1970. See Rev. Rul. 70101, 1970-1 C.B. 278 (1970) (ruling that it will treat professional corporations as corporations for tax purposes). For a discussion of the Treasury's losing war with professional associations, see Hobbs, supra, at 488-91. 
Under the incorporation rule previously discussed, ${ }^{195}$ it is arguable whether the mechanical Kintner Regulations were valid because they were inconsistent with Morrissey's overall facts and circumstances standard in determining what constitutes an association. ${ }^{196}$ The regulations did, however, retain the corporate resemblance framework, using the very same factors identified in Morrissey. In support of the regulations, one could argue that they merely provide a permissible clarification of the Morrissey framework. In Chevron terms, Morrissey left some gaps to fill (i.e., how much weight to give each factor and how much overall resemblance was required) and the Treasury arguably filled these gaps in a reasonable manner. ${ }^{197}$ Although commentators criticized the regulations as straying from the Morrissey standard, ${ }^{198}$ they were never challenged on that ground during their thirty-six-year existence. ${ }^{199}$ Thus, no court ever considered whether the regulations were invalid in light of Morrissey.

\section{The Enactment of $\$ 7704$}

The next major development in the tax classification of business entities was Congress's enactment of $\S 7704$ in 1987.200 Section 7704 automatically classified publicly traded partnerships as corporations, even though they would not be so classified under the Kintner Regulations. ${ }^{201}$ Prior to the enactment of $\S 7704$, these publicly traded partnerships were structured to fail two corporate characteristics in order to avoid corporate status; ${ }^{202}$ however, in practical

195 See supra text accompanying notes $92-101$.

196 See supra text accompanying notes 191-197 (describing the differences between the Kintner Regulations and the Morrissey standard).

197 See White, supra note 19, at 759 (arguing that, "when a silence or ambiguity exists in the Court's construction of the statute, realization of the values underlying Chevron is best accomplished when the Court defers to the agency's resolution of such policy choices").

i98 See, e.g., Scallen, supra note 179, at 693-94 (criticizing the Kintner Regulations as inconsistent with Morrissey and subsequent case law).

199 See 1 MCKEE ET AL., supra note 1, ๆ 3.06, at 3-58 n.223 (noting that the validity of the Kintner Regulations was never challenged).

200 See Revenue Act of 1987, Pub. L. No. 100-203, § 10211, 101 Stat. 1330-382, 1330 403 (1987).

${ }^{201}$ See I.R.C. $\S 7704(a)$, (b) (treating partnerships that are publicly traded as corporations).

202 These partnerships typically did not exhibit the corporate characteristics of limited liability and perpetual existence. See, e.g., Larson v. Comm'r, 66 T.C. 159, 175, 183, 185 (1976) (concluding that the two limited partnerships involved were not taxable as corporations under the Kintner Regulations because they lacked the corporate characteristics of limited liability and perpetual existence). These entities generally failed to meet the perpetual existence standard because they would automatically dissolve upon the will or bankruptcy of a general partner and failed limited liability because a sufficiently capitalized general partner remained responsible for the partnership's debts. See, e.g., id. at 173-75, 179-82. 
effect, they operated much like publicly traded corporations. ${ }^{203}$ The impetus behind $\S 7704$ was congressional concern that, because of the similarity between these partnerships and publicly traded corporations, the publicly traded partnership would soon become the entity of choice for publicly traded businesses, resulting in a significant erosion of the corporate tax base. ${ }^{204}$ To prevent this erosion, $\S 7704$ automatically classified publicly traded partnerships as corporations, ensuring consistent tax treatment for these entities and publicly-traded corporations. ${ }^{205}$

It is important to emphasize that $\$ 7704$ was built upon the groundwork laid by Morrissey. The text of $\S 7704$ clearly indicates that the section concerns only partnerships, ${ }^{206}$ which were defined through an application of the corporate resemblance test at the time $\S 7704$ was enacted. ${ }^{207}$ Therefore, in

203 See H.R. REP. No. 100-391(II), at 1066 (1987), reprinted in 1987 U.S.C.C.A.N. 2313378, 2313-681 (reasoning that "[p]ublicly traded partnerships resemble publicly traded corporations in their business functions and in the way their interests are marketed, and limited partners as a practical matter resemble corporate shareholders").

204 See $i d$. at 1065 (remarking that "[t]he recent proliferation of publicly traded partnerships... has caused concern about long-term erosion of the corporate tax base"). See also STAFF OF JOINT COMM. ON TAXATION, 100TH CONG., TAX TREATMENT OF MASTER LIMITED PARTNERSHIPS 31-34 (Comm. Print 1987) [hereinafter MLP REPORT] (discussing potential erosion of the corporate tax base). With regard to the proliferation of publicly traded partnerships, there were concerns other than the erosion of the corporate tax base. As a practical matter, only certain types of businesses would have the opportunity to use the publicly traded partnership form and avoid the corporate tax, resulting in a tax-created competitive advantage for these businesses. See id. at 35 . In addition, there was some concern that the highly complex partnership tax rules governing partnerships were not well designed to deal with entities with a substantial number of owners. See id. at 24-25.

205 I.R.C. $\$ 7704$ (a) (indicating that "a publicly traded partnership shall be treated as a corporation"). For purposes of $\S 7704$, the term "publicly traded partnership" is generally defined as any partnership the interests of which are either "traded on an established securities market" or "are readily tradable on a secondary market." Id. $\S 7704($ b). Certain partnerships with primarily passive income are excluded from the definition. See id. $\S$ 7704(c), (d) (exempting a publicly traded partnership from being treated as a corporation if ninety percent of its income is derived from interest, dividends, real property rents or sales, mining, sales of capital assets, commodities, futures, forwards, and options). In addition, $\S 7704(\mathrm{~g})$ provides for transition rules for certain publicly traded partnerships in existence prior to the enactment of $\S 7704$. See id. $\S 7704$ (g) (providing opportunity for existing partnerships to elect a $3.5 \%$ tax on gross income instead of being taxed as a corporation). For a detailed discussion of $\S 7704$ and related regulations, see 1 MCKEE ET AL., supra note $1,93.09$, at 3-116 to 3-127.

206 See I.R.C. $\S 7704$ (b) (defining the term "publicly traded partnership" as any partnership whose interests are "traded on an established securities market" or "readily tradable on a secondary market").

207 See MLP REPORT, supra note 204, at 8 (describing how the Kintner Regulations enacted after Morrissey classified business entities as partnerships or corporations via the corporate resemblance test). 
determining whether an entity was subject to $\S 7704$, the first step was to analyze whether the entity constituted a partnership under such test. ${ }^{208}$ Only after concluding that the entity was a partnership would the second step of determining whether the entity was publicly traded become necessary. ${ }^{209}$ As a result, the text of $\S 7704$ clearly indicates that, in enacting the provision, Congress was aware of the corporate resemblance test then applicable. ${ }^{210}$

After the enactment of $\S 7704$, all publicly traded entities would be taxable as corporations. ${ }^{211}$ Accordingly, the Morrissey standard remained relevant only in the classification of unincorporated, nonpublicly-traded entities. It is in this context that the next major development in the tax classification of business entities occurred.

\section{The Proliferation of the Limited Liability Company}

Beginning in the late 1980 s, a novel business entity form began to grow in popularity. ${ }^{212}$ This entity, the limited liability company ("LLC"), was designed by states to combine the most beneficial attribute of the partnership form (single level of taxation) with the most beneficial attribute of the corporate form (limited liability). ${ }^{213}$ The LLC statutes also generally allowed owners the flexibility to choose among the less important corporate factors of centralized management, free transferability of interests, and perpetual existence..$^{214}$ Importantly, because these statutes allowed a particular entity to fail at least

208 See I.R.C. $\$ 7704(b)$.

209 See id.

210 See id; see also H.R. CONF. REP. No. 100-495, at 943-45 (1987), reprinted in 1987 U.S.C.C.A.N. 2313-1245, 2313-1689 to 2313-1690; H.R. REP. No. 100-391(II), pt. B(1), at 1063-67 (1987), reprinted in 1987 U.S.C.C.A.N. 2313-378, 2313-678 to 2313-682 (discussing the corporate resemblance standard and recognizing that $\S 7704$ would apply to publicly traded entities that otherwise would be classified as partnerships under such standard).

211 See I.R.C. $\$ 7704$ (a) (automatically classifying publicly traded partnerships as corporations).

212 See Hobbs, supra note 194, at 515-17 (describing the proliferation of the limited liability company after the IRS issued Rev. Rul. 88-76, 1988-2 C.B. 360, 360-61, which classified a limited liability company formed under Wyoming law as a partnership for federal income tax purposes).

213 See George Mundstock, A UnIFIEd ApproaCh to SubChapters K \& S 10 (2002) (observing that " $[t]$ he LLC provides the single-tax and tax loss pass-through benefits of [partnerships] with limited state-law liability"); Hobbs, supra note 194, at 510 (characterizing LLCs as combining "the limited liability of corporations with the tax aspects of partnerships").

214 See, e.g., Rev. Rul. 93-38, 1993-1 C.B. 233, 235-36 (describing a Delaware statute that allowed owners to opt-in to the secondary corporate characteristics of free transferability, continuity of life, and centralized management); see also 1 BITTKER \& EUSTICE, supra note 3, ๆ 2.05[2], at 2-34 ("LLC statutes often create choices to be exercised in the LLC's organizing agreement."). 
two of these secondary corporate attributes, they ensured that, with proper planning, the entity would not be classified as an association under the Kintner Regulations. ${ }^{215}$

As a result, by using the LLC form, any non-publicly traded business could combine pass-through taxation, limited liability, and one of the secondary corporate characteristics. Furthermore, because the two forgone secondary corporate characteristics were generally insignificant to a closely held business, ${ }^{216}$ the LLC allowed owners to easily accommodate all of their important goals. ${ }^{217}$

Like the publicly traded partnership, the LLC highlighted the inadequacies of the corporate resemblance test, this time in the non-publicly traded context. Closely held LLCs looked and behaved in all important respects like closely held corporations yet were taxed differently because of relatively insignificant distinctions. Recognizing this and tiring of the perpetual classification battles with taxpayers, the Treasury finally capitulated in 1996 with the promulgation of the "check-the-box" regulations. ${ }^{218}$

\section{ANALYSIS OF THE VALIDITY OF THE CHECK-THE-BOX REGULATIONS}

The check-the-box regulations, which became effective on January 1, $1997,{ }^{219}$ marked the apparent end of the corporate resemblance test. These regulations provided that, for purposes of $\S 7701(a)(3)$, any unincorporated business entity generally could elect whether or not to be classified as an association, ${ }^{220}$ unless it was a publicly traded partnership covered by $\S 7704.221$ Therefore, after the promulgation of these regulations, a non-publicly traded, unincorporated business could generally elect whether or not to be subject to

215 See 1 BITTKER \& EuSTICE, supra note 3, ๆ 2.05[2], at 2-34 (explaining that state statues allow LLCs to plan to be classified as either partnerships or associations for tax purposes). Some statutes were designed to be fool-proof in ensuring non-association status by preventing the LLC from having more than two corporate characteristics. See, e.g.,

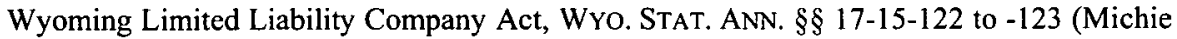
2003) (ensuring that Wyoming LLCs would lack the corporate characteristics of continuity of life and free transferability).

216 See Hobbs, supra note 194, at 514 (explaining that the owners of closely held businesses generally did not care about continuity of life or free transferability of interests).

217 See id.

21861 Fed. Reg. 66584, 66584-85 (Dec. 18, 1996) (to be codified at 26 C.F.R. pts. 1, 301,602 ) (summarizing regulations providing a generally elective system for classifying business organizations effective January 1, 1997).

${ }^{219} \mathrm{Id}$. at 66584.

220 Treas. Reg. $\$ 301.7701-3$ (as amended in 2001).

${ }^{221}$ Treas. Reg. $\S 301.7701-2(b)(7)$. In addition, certain foreign entities, such as the Mexican Sociedad Anonima, are treated as per se corporations under the regulations. Treas. Reg. $\S 301.7701-2(b)(8)$ (listing entities in eighty jurisdictions that are automatically regarded as corporations). The regulations also provide default rules that classify entities in the absence of an affirmative election. See infra text accompanying notes 318-321. 
the corporate tax.

The regulations were praised from the beginning. The leading corporate tax treatise remarked that the regulations "were concise, clear, and surprisingly simple ... and they were happily embraced by tax practitioners with near unanimity."222 The prestigious Tax Section of the New York State Bar Association called the elective regime a "bold and innovative proposal that would avoid the substantial expenditure of resources on entity classification issues that is required of both taxpayers and the government under the traditional four-factor test." 223 Lost in this overwhelming praise, however, was any serious discussion of whether the regulations' elective methodology was foreclosed by the Supreme Court's decision in Morrissey.

\section{A. The Validity of the Regulations under a Chevron Analysis}

From the outset, the government was concerned about whether the Treasury had the authority to issue these regulations. For example, when the IRS first raised the possibility of an elective regime, it requested public commentary regarding the appropriateness of implementing it via regulatory action. ${ }^{224}$ Although there was not unanimity, the clear consensus was that the Treasury had the requisite authority. As discussed below, however, the commentators focused exclusively on the regulations' validity under the Chevron two step methodology, failing to recognize that, because of the incorporation rule, that analysis was misplaced and irrelevant.

\section{Arguments Made Against Validity}

Among the commentary, the distinct minority view was that the Treasury lacked authority to promulgate the regulations. The basis for this view was that the statutory language itself, rather than Morrissey, foreclosed any possibility of an elective regime. Thus, these arguments were all grounded in Chevron step one in that they were premised on the idea that Congress had specifically ruled out an elective regime.

Although all of the arguments for invalidity were based on plain meaning, the formulations of the argument differed slightly among commentators. Some argued that an elective regime was simply foreclosed by the statutory language in $\S 7701(\mathrm{a})(3)$, which indicated that Congress intended the term "association" to have substantive meaning. ${ }^{225}$ Others argued that the statutory scheme in

2221 BITTKER \& EUSTICE, supra note 3, ๆ 2.02[3][a], at 2-13.

${ }^{223}$ N.Y. State Bar Ass'n Tax Section, Report on the "Check the Box" Entity Classification System Proposed in Notice 95-14, TAX NotES TODAY, Sept. 5, 1995, available at LEXIS 95 TNT 147-46 [hereinafter NY State Bar Report].

${ }^{224}$ I.R.S. Notice 95-14, 1995-1 C.B. 297, 299.

225 See Susan Pace Hamill, A Case for Eliminating the Partnership Regulations, 68 TAX NOTES 335, 337 n. 15 (July 17, 1995), available at LEXIS 68 TN 335 (arguing that, because the Code "defin[es] 'corporation' to include 'associations'[, it] clearly contemplates that at least some unincorporated organizations will be classified as associations and subject to the 
$\S \S 7701(a)(2)$ and (a)(3), which define "corporation" and "partnership" as mutually exclusive, mandated that two entities which are identical in all substantive respects may not be classified inconsistently. 226

\section{Arguments Made in Favor of Validity}

The vast majority of commentators found the regulations to be permissible. 227 In general, these commentators concluded that the term "association" had no plain meaning under Chevron step one ${ }^{228}$ and then

corporate tax provisions"); Philip F. Postlewaite \& John S. Pennell, JCT's Partnership Tax Proposals-'Houston, We Have a Problem', 76 TAX Notes 527, 532 (July 28, 1997), available at LEXIS 76 TN 527 (concluding that "it appears irrefutable that implicit in the statutory formulation is that the taxpayer... is not entitled to determine the enterprise's classification by a mere expression of preference").

${ }^{226}$ See 1 MCKEE ET AL., supra note 1, I 3.08, at 3-102 (suggesting that Treasury exceeded its authority when it promulgated "a rule that permits substantively identical entities to elect to be classified as either an association taxable as a corporation or a partnership").

227 See, e.g., Am. Bar Ass'n Section of Taxation, Comments on Notice 95-14, 1995-14 I.R.B. 7, Proposed Revisions to the Entity Classification Rules, TAX NOTES TODAY, July 26, 1995, available at LEXIS 95 TNT 145-25 [hereafter Tax Section Report]; Ass'n of the Bar of the City of N.Y., Comm. on Taxation of Partnerships and Other Pass-Through Entities, Report on "Check-the-Box" Proposal for Entity Classification (Notice 95-14), TAX NOTES TODAY, Aug. 24, 1995, available at LEXIS 95 TNT 166-43 [hereinafter Bar of NYC Report]; NY State Bar Report, supra note 223; see also Victor E. Fleischer, Note, "If It Looks Like a Duck": Corporate Resemblance and Check-the-Box Elective Tax Classification, 96 COLUM. L. REV. 518, 532-37 (1996).

228 See, e.g., Bar of NYC Report, supra note 227 (maintaining that because the Code does not define the term "association," it gives Treasury authority to define the term); NY State Bar Report, supra note 223 (arguing that because the terms "association" and "partnership" are not defined in the tax code, the Treasury has regulatory authority to define those terms and implement the check-the-box system); see also Fleischer, supra note 227, at 535 (concluding that the check-the-box regulations survive step one because the term "association" lacks plain meaning). This application of Chevron step one (asking whether the term at issue has a plain meaning) is a narrow view of that step. See Levin, supra note 37, at 1283. In step one, Chevron asked whether Congress has "directly addressed the precise question at issue." Chevron U.S.A., Inc. v. Natural Res. Def. Council, Inc., 467 U.S. 837,843 (1984). A broader view of step one, and the one used by the commentators who argued that the check-the-box regulations were invalid, would formulate the "precise question at issue" as whether Congress had ruled out the interpretation proffered by the agency. See Levin, supra note 37, at 1283 (predicting that if one frames the "precise question at issue' as whether Congress has ruled out an option the agency has chosen, the stage may be set for reversal at step one"). The Supreme Court has occasionally framed the step one inquiry in this broad manner. See, e.g., City of Chicago v. Envtl. Def. Fund, 511 U.S. 328, 339 (1994) (finding Congress ruled out exempting Chicago's use of an ash incinerator from hazardous waste regulation under the Resource Conservation and Recovery Act of 1976); Pittston Coal Group v. Sebben, 488 U.S. 105, 113-14 (1988) (holding Congress ruled out more restrictive regulations promulgated by the Secretary of Labor in the 
determined that the elective regime was reasonable under step two. ${ }^{229}$

In concluding that the regulations survived step two, proponents of the regulations generally made one of two arguments. Some proponents argued that the corporate resemblance test as clarified by the Kintner Regulations had effectively become an elective regime; therefore, according to these proponents, the regulations were merely "a change in form rather than in substance." 230 This point is dubious, as explained by Philip Postlewaite and John Pennell, who noted, "If the prior classification system was truly elective, then what need was there for the new regulations? If not, then the check-thebox approach is an alteration of the classification system."231 Simply put, under the corporate resemblance test, an unincorporated entity with more than two of the substantive corporate characteristics could not avoid corporate treatment. Under the check-the-box regime, this was now possible. ${ }^{232}$ Accordingly, contrary to the arguments of these proponents, the check-the-box regulations did substantively change the classification test.

Other proponents conceded that the regulations made a substantive change, but argued that the policy choice made by Treasury was reasonable and therefore permissible under Chevron. ${ }^{233}$ These commentators argued that, when viewed in conjunction with the publicly traded partnership provision in $\S 7704$, the regulations constituted a reasonable implementation of the

Black Lung Benefits Reform Act of 1977); INS v. Cardoza-Fonseca, 480 U.S. 421, 445-48 (1987) (holding that two standards through which an alien may seek relief in the Immigration and Nationality Act are distinct despite interpretation of Board of Immigration Appeals that they are equivalent). Because the narrow view will often result in the court moving on to lenient step two, this view would also increase the likelihood of the court upholding the agency interpretation. See Levin, supra note 37, at 1282 (observing that, where the court has used the narrow view of step one, it "[ $\mathrm{u}]$ sually . . . leads to affirmance of the agency's action").

229 See, e.g., Fleischer, supra note 227, at 549 (concluding that the regulations implement the congressional mandate in a reasonable manner).

230 JCT REPORT, supra note 12, at 15. See also Tax Section Report, supra note 227 (concluding that the regulations would be valid because under the Kintner Regulations, "taxpayers [could] in effect, elect whether to have their business enterprises classified as corporations or partnerships . ..."); Bar of NYC Report, supra note 227 (concluding that the regulations would be valid because the pre-check-the-box regime "in effect[] already provide an election"); NY State Bar Report, supra note 223 (arguing that because the regulations would "codify the effectively elective nature of the current classification system, as well as reduce burdens on taxpayers and the government,... the Treasury has the authority to promulgate such regulations").

231 Postlewaite \& Pennell, supra note 225, at 531 n.36.

232 See State Bar of Cal. Taxation Section, "Check the Box" Elective Partnership Taxation and Reduced Cost Entity Conversions: A Proposal for Simplicity and Horizontal Equity, TAX NOTES TODAY, July 28, 1995, available at LEXIS 95 TNT 147-41 (observing that under pre-check-the-box law, an LLC could not have all four corporate characteristics and qualify for flow-through tax treatment).

${ }^{233}$ See JCT REPORT, supra note 12, at 14-15; Fleischer, supra note 227, at 544-49. 
congressional mandate in $\S 7701(\mathrm{a})(3)$ that corporate-like entities be taxed as corporations. ${ }^{234}$ Commentators supporting this view observed that, under a check-the-box regime, only publicly traded entities would generally be subject to the corporate tax because closely held organizations would almost always elect partnership classification. ${ }^{235}$ As a result, the argument went, the checkthe-box regulations merely "shift the focus of the resemblance test to the pivotal factor of whether an unincorporated organization is publicly traded."236 Furthermore, according to these commentators, using public trading as a proxy for "corporateness" is a wise policy choice. ${ }^{237}$

The argument that public trading should, as a policy matter, be the distinguishing feature in determining whether an entity should be subject to the corporate tax has a good deal of merit. ${ }^{238}$ It remains difficult, if not impossible, however, to reconcile this notion with the statute because the regulations interpret the statutory term "association" as devoid of any substantive meaning. ${ }^{239}$ Even though $\S 7704$ in effect automatically treats publicly traded partnerships as associations, when Congress enacted the provision, it left the historical definition of corporation as including "associations" intact. ${ }^{240}$ By leaving this definition untouched in the process of radically changing the classification landscape, Congress indicated a clear intention that entities other than publicly traded partnerships and state-law corporations be treated as corporations for tax purposes. Thus, even though the regulations may represent a reasonable or even wise policy choice, it appears difficult to square them with the language of $\S 7701$ (a)(3).

Nevertheless, since this article argues that one never even gets to Chevron because of Morrissey and the incorporation rule, it is not necessary to resolve the question of whether the check-the-box regulations would survive a Chevron analysis. Accordingly, even though there are very strong arguments that the regulations would not survive a Chevron analysis, for the remainder of this article it is assumed that the regulations would be upheld under Chevron had they been issued on a clean slate. ${ }^{241}$

234 See JCT REPORT, supra note 12 at 15-16; Fleischer, supra note 227, at 544-49.

235 See Fleischer, supra note 227 , at 542.

236 See id. at 522.

237 See id. at 549-55.

${ }^{238}$ See id. at 553-55 (arguing that using public trading is wise because it will not significantly decrease the corporate tax base, it will simplify the law, and it will bring tax law more in line with securities law). In fact, because the check-the-box regulations have remained in effect since 1997, the publicly traded distinction is the one that has been in place since then. There has been no discussion about terminating the elective regime, which supports the notion that the publicly traded distinction has survived the test of time thus far.

${ }^{239}$ See supra text accompanying note 225 (observing that Congress intended "association" to have substantive meaning in $\S 7701$ (a)(3)).

240 See supra text accompanying notes 206-210.

${ }^{241}$ By using the term "issued on a clean slate," I mean if the regulations were issued in the absence of Morrissey or any other judicial interpretation of the term "association." 


\section{B. Appropriate Analysis of the Validity of the Check-the-Box Regulations}

Despite the Treasury's initial concern about the validity of the check-thebox regulations and the voluminous commentary devoted to the issue, the incorporation rule has never been discussed with regard to the regulations. Although a few commentators briefly alluded to the general notion that Morrissey's interpretation of association might foreclose an elective regime, ${ }^{242}$ none of the trilogy of cases underlying the incorporation rule were ever cited or discussed. ${ }^{243}$ This failure is particularly striking given the importance of the regulations, the wealth of commentary on the regulations, and the identity of those who specifically commented on the regulations' validity, including the Joint Committee on Taxation and the tax sections of the New York and California state bar associations.

\section{Application of the Incorporation Rule}

Applying the incorporation rule to the check-the-box regulations is relatively straightforward. In Morrissey, the Supreme Court independently interpreted the term "association" to mean any unincorporated entity that

${ }^{242}$ See, e.g., JCT REPORT, supra note 12, at 15 ("Some might argue that the Morrissey decision requires the Treasury Department to apply a corporate resemblance test in any regulations for determining whether an entity is an association taxable as a corporation."); NY State Bar Report, supra note 223 (arguing that although it believes the regulations to be valid, "it is possible to construct an argument that Treasury does not have the authority to adopt the 'check the box' system by way of regulation, which argument would rely on the fact that the four-factor test is grounded in the early case law that purports to classify based upon corporate resemblance."); see also William B. Brannan, The Subchapter K Reform Act of 1997, 75 TAX NOTES 121, 141 n.106 (Apr. 7, 1997), available at LEXIS 75 TN 121 (explaining that while he "is alarmed about the suggestion" that the regulations might be invalid, the "principal argument [in favor of invalidity] would be that the corporate resemblance approach reflected in the prior regulations were [sic] grounded in established case law beginning with ... Morrissey ... and, therefore, the Treasury Department could not now fundamentally change the classification law by adopting new regulations"); Hamill, supra note 225, at $337 \mathrm{n} .15$ (arguing that the regulations are invalid because they "eliminat[e] the relevance of the corporate resemblance test, [thereby] completely overturn[ing] the Supreme Court's interpretation of section 7701(a)(3) that has been in force for 60 years"). Notably, Professor Hamill was the only commentator to definitively conclude that the regulations would be invalid on the grounds that they conflict with Morrissey, although she did not cite the cases underlying the incorporation rule in support of her position.

${ }^{243}$ All of the commentary except for the Joint Committee on Taxation's was published before $\mathrm{Neal}$, the last case in the trilogy, was decided on January 22, 1996. See Neal v. United States, 516 U.S. 284 (1996). All of the commentary, however, was published well after the second case of the trilogy, Lechmere, Inc. v. NLRB, was decided on January 27, 1992. See Lechmere, Inc. v. NLRB, 502 U.S. 527 (1992). The Joint Committee's report, which specifically and extensively discussed the issue of whether the regulations were valid, was published on April 8, 1997, well after the Neal decision. See JCT REPORT, supra note 12 , at 13-17. 
sufficiently resembled a corporation and instructed that, in determining resemblance, the four corporate characteristics were to be analyzed. ${ }^{244}$ This definition was the result of an independent judicial interpretation made after "a further examination of the congressional intent"; 245 it was not made in deference to the government's position, which was explicitly rejected by the Court. 246

Under the incorporation rule, the Supreme Court definition effectively became part of the governing statute, at least until the Court overrules its precedent or Congress amends the statute. ${ }^{247}$ The check-the-box regulations, which allow an entity that has all four corporate characteristics to avoid association status, are inconsistent with the Morrissey definition, which would classify such an entity as an association. Because of this inconsistency and because Congress has not amended the definition of corporation in $\S 7701(\mathrm{a})(3)$, the regulations are invalid.

\section{Possible Counter-Arguments}

There are five colorable arguments that could be made in an attempt to save the regulations from invalidity, but all are ultimately unpersuasive. These arguments are discussed below, beginning with two made by the Joint Committee on Taxation.

\section{a. Consistency with Morrissey}

The Joint Committee made the following argument in response to the general notion that Morrissey might foreclose an elective regime:

Some might argue that the Morrissey decision requires the Treasury Department to apply a corporate resemblance test in any regulations for determining whether an entity is an association taxable as a corporation. On the other hand, it has been argued that the check-the-box regulations in fact represent an implementation of the corporate resemblance test, when viewed in conjunction with the present-law rules generally treating publicly traded partnerships as corporations. The publicly traded partnership rules could be viewed as reflecting a determination by Congress that public trading is an effective index of whether an entity resembles a corporation. ${ }^{248}$

This argument appears to be based on the view that the check-the-box regime

244 See supra text accompanying notes 176-179 (identifying the four factors to be applied).

245 Morrissey v. Comm'r, 296 U.S. 344, 356 (1935).

246 See supra text accompanying notes $172-179$ (observing that Morrissey rejected the business enterprise test that the governing regulation used and that was the basis of the government's argument that the trust constituted an association).

247 See supra text accompanying notes $92-101$.

248 JCT REPORT, supra note 12, at 15-16 (footnotes omitted). 
is not inconsistent with the holding in Morrissey. Under this view, the checkthe-box regime merely changes the "index" of corporate resemblance from the four-factor test to public trading.

This argument is unpersuasive regardless of whether one takes an expansive or narrow view of Morrissey's holding. Under a broad view, Morrissey instructed a reviewing court to analyze the four identified corporate factors, ${ }^{249}$ which is clearly inconsistent with the check-the-box regime under which these factors are irrelevant. ${ }^{250}$ In other words, Morrissey explicitly provided the index of corporate resemblance and any change of that index is inconsistent with this broad view. of Morrissey's holding.

Under a narrow view, the Court held that an unincorporated business entity with all four corporate characteristics constitutes an association. ${ }^{251}$ This is also inconsistent with the check-the-box regime where such an entity would be able to elect its classification. ${ }^{252}$ Therefore, under the check-the-box regulations, the actual outcome in Morrissey would have been different. Accordingly, when viewed from either a broad or narrow perspective, the holding of Morrissey is incompatible with an elective regime.

\section{b. Super-Chevron Powers in Entity Classification?}

In addressing the concern that Morrissey might foreclose an elective regime, the Joint Committee noted that "the standard of review articulated in the Morrissey case ... grant[s] the Treasury Department considerable leeway to devise a different [classification] test," ${ }^{253}$ citing the following language from Morrissey:

As the statute merely provided the term "corporation" should include "associations," without further definition, the Treasury department was authorized to supply rules for the enforcement of the Act within the permissible bounds of administrative construction. Nor can this authority be deemed to be so restricted that the regulations, once issued, could not later be clarified or enlarged so as to meet administrative exigencies or conform to judicial decision. 254

Other proponents of the regulations also suggested that this language gave the Treasury extremely broad latitude, a sort of "super-Chevron" power, in developing classification tests. ${ }^{255}$

249 See Morrissey, 296 U.S. at 359.

250 See Treas. Reg. $\S 301.7701-3$ (a) (as amended in 2003) (allowing unincorporated entities to elect their classification).

251 See Morrissey, 296 U.S. at 360-61.

${ }^{252}$ See Treas. Reg. $\S 301.7701-3$ (a) (allowing unincorporated entities to elect their classifications).

253 JCT Report, supra note 12, at 16.

254 Id. at 16 n.27 (quoting Morrissey v. Comm'r, 296 U.S. 344, 354-55 (1935) (emphasis added)).

${ }^{255}$ See, e.g., Tax Section Report, supra note 227 (arguing that this language gives "the 
These commentators, however, read this language entirely out of context. In the excerpt above, the Court was specifically responding to the trust's argument that the Treasury's old regulatory standard, pursuant to which the trust would be treated as an association only if the beneficiaries had control over the corpus, was binding on the government. ${ }^{256}$ The Court was simply explaining that the Treasury was not bound by its superceded regulations. The Court was not addressing the different and much more radical notion that the Treasury could, in the course of issuing a new regulation, disregard a prior Supreme Court decision directly on point. As a result, this language does not support the validity of the regulations.

\section{c. Alternatives to the Incorporation Rule}

A proponent of the check-the-box regulations might also argue that the Court should overrule the trilogy of cases underlying the incorporation rule. As previously discussed, the incorporation rule undermines the Chevron principle that politically accountable agencies, rather than politically insulated judges, should bear primary interpretative responsibility with regard to ambiguous agency-administered statutes. ${ }^{257}$ Furthermore, the rule restricts the flexibility granted by Chevron, which allows agencies to deal with changed circumstances. ${ }^{258}$ In addition to undermining Chevron, the incorporation rule places undue importance on timing, ${ }^{259}$ which itself creates improper incentives for both agencies ${ }^{260}$ and courts..$^{261}$

As a result, some have suggested that the incorporation rule should be overruled judicially in favor of a different methodology for resolving the conflict between stare decisis and Chevron. Two approaches have recently been discussed.

\section{i. Re-Examination Approach}

Thomas Merrill and Kristin Hickman have discussed the conflict between stare decisis and Chevron in cases where a pre-Chevron judicial interpretation conflicts with a later Mead-qualified agency interpretation. ${ }^{262}$ They considered

Treasury . . . broad latitude to promulgate regulations in this area"); Tax Executives Inst., Inc., Comments of Tax Executives Institute, Inc. on Notice 95-14 Relating to Entity Classification, TAX NOTES TODAY, July 28, 1995, available at LEXIS 95 TNT 147-41 (arguing that the language "confirms Treasury's authority to amend the regulations 'to meet administrative exigencies"').

${ }^{256}$ See supra text accompanying notes 168-170 (finding that the Revenue Act of 1924 did not bind Treasury to its previous regulations regarding the definition of association).

257 Supra text accompanying notes 108-109.

258 Supra text accompanying note 110.

259 Supra text accompanying notes 111-113.

260 See supra text accompanying notes 117-119.

261 See supra text accompanying notes 120-121.

${ }^{262}$ See Merrill \& Hickman, supra note 40, at 915-20. 
"the need for a transitional rule-a special rule of adjustment that mediates between the pre-Chevron and the post-Chevron worlds." 263

There are really only two options for [pre-Chevron] decisions. One is to examine each pre-Chevron precedent on a case-by-case basis, in an attempt to determine as best as is possible whether the precedent would have been a step-one precedent or a step-two precedent if, counterfactually, the court had applied the Chevron doctrine. The other is to adopt a blanket presumption that all pre-Chevron precedent is step-one precedent.... The Supreme Court's treatment of its own precedent is best understood as adopting the second option-the blanket presumption that all past Supreme Court precedents are step-one precedents. ${ }^{264}$

In Merrill and Hickman's terminology, the incorporation rule can be understood as "a blanket presumption that all pre-Chevron [Supreme Court] precedent is step-one precedent." 265 Branding this precedent automatically as step one precedent has the same effect as treating the judicial interpretation as incorporated into the statute because the agency would be similarly bound in either case. ${ }^{266}$ Applying this blanket step one approach, the check-the-box regulations would be invalid since they are inconsistent with the Court's deemed step one interpretation of the term "association."

The result is the same even under Merrill and Hickman's re-examination of the pre-Chevron precedent approach. Applying this approach to Morrissey, one would re-examine the opinion to best determine whether the case "correspond[s] to either step one or step two of Chevron."267 This is another way of asking whether the case would fall under the independent judgment model (where the court independently determined the meaning of the term) or the deferential model (where the court deferred to any reasonable agency

263 Id. at 916.

264 Id. at 917 . Merrill and Hickman do not address the similar conflict that arises when a judicial interpretation that was made post-Chevron (but without the benefit of a Meadqualified agency interpretation) is inconsistent with a later Mead-qualified interpretation. See Bamberger, supra note 18, at 1296-1301. Rather, they focused only on the transitional issue of how to treat a pre-Chevron judicial interpretation in a post-Chevron world. See Merrill \& Hickman, supra note 40, at 917.

265 See Merrill \& Hickman, supra note 40, at 917.

266 There might be a slight difference between these two approaches with regard to the Court's willingness to overrule its prior interpretation. It is unclear, under Merrill and Hickman's blanket step one presumption, how the Court would decide whether to overrule its precedent.

267 Id. at 918 . Although the language quoted in the text accompanying note 264 , supra, might suggest that the re-examination approach would require the Court to speculate as to what the pre-Chevron court actually would have done had it applied Chevron, it is clear that this is not what Merrill and Hickman suggest. Rather, under the re-examination approach, the pre-Chevron decision is analyzed closely to determine whether it better corresponds with step one or step two under Chevron. See Merrill \& Hickman, supra note 40, at 918. 
definition). ${ }^{268}$ As previously discussed, the Court in Morrissey rejected the government's view and independently interpreted the statutory language at issue. ${ }^{269}$ As a result, even under this re-examination approach, the check-thebox regulations would be invalid. 270

\section{ii. Provisional Precedent Approach}

Kenneth Bamberger recently proposed a more radical alternative to the incorporation rule. ${ }^{271}$ To address the problems resulting from the incorporation rule, Bamberger proposed giving judicial interpretations of ambiguous agencyadministered statutes only provisional stare decisis effect. ${ }^{272}$ Under this approach, when Congress leaves ambiguity to agency discretion, "a judicial choice of one option within the zone of indeterminacy, although it would be authoritative in resolving the case or controversy, would constitute binding precedent only until an agency puts forth a different one in a manner deserving Chevron treatment."'273 In other words, a rule of provisional precedent would allow a Mead-qualified agency interpretation to trump a judicial interpretation so long as the agency interpretation would be upheld under Chevron. ${ }^{274}$

If the Court adopted Bamberger's proposal of provisional precedent, the validity of check-the-box regulations would be analyzed very differently. Morrissey, because it acknowledged that the term "association" was ambiguous, ${ }^{275}$ would be considered provisional precedent subject to subsequent Mead-qualified Treasury action that passes the Chevron standard. ${ }^{276}$ Therefore, assuming that the check-the-box regulations were issued in a form that qualifies for Chevron deference under Mead, ${ }^{277}$ the

268 See supra Part 1.A.

269 See supra text accompanying notes 162-179.

270 Merrill and Hickman ultimately support the blanket step one presumption as the best transition rule, concluding that the benefits of the re-examination approach would be outweighed by its difficulties and inefficiencies. See Merrill \& Hickman, supra note 40 , at 918-20.

271 Bamberger, supra note 18, at 1310-20 (outlining provisional precedent analysis).

272 Id. at 1310-11.

${ }^{273} \mathrm{Id}$. at 1311.

$274 \mathrm{Id}$.

275 Morrissey v. Comm'r, 296 U.S. 344, 356 (1935).

${ }^{276}$ By acknowledging that the term was ambiguous, Morrissey leaves the Treasury the opportunity to amend the judicial interpretation by regulation under a rule of provisional precedent. See Bamberger, supra note 18, at 1310-11. If the Court had found plain meaning in Morrissey, then a subsequent inconsistent Treasury regulation would be invalid even under this rule not because it conflicted with judicial precedent, but because it conflicted with the plain meaning of the statute (as previously determined by the Court) under Chevron step one. See Chevron U.S.A., Inc. v. Natural Res. Def. Council, Inc., 467 U.S. 837, 842-43 (1984).

277 See supra Part I.E.3 (discussing whether general authority regulations qualify for Chevron deference under Mead). 
regulations would be upheld if they pass Chevron's two step analysis. ${ }^{278}$

Accordingly, if the Court adopted a rule of provisional precedent, the regulations might be saved. While a full analysis of Bamberger's proposal is beyond the scope of this article, it is enough to say that it is unlikely to be adopted by the Court in the near term simply because it would represent "a landmark abdication of judicial power."279 In this regard, Justice Scalia notes:

I know of no case, in the entire history of the federal courts, in which we have allowed a judicial interpretation of a statute to be set aside by an agency - or have allowed a lower court to render an interpretation of a statute subject to correction by an agency. ${ }^{280}$

Indeed, "there would be something unsettling about a world in which executive branch administrators could 'overrule' Supreme Court decisions."281

\section{d. Overruling Morrissey}

A proponent of the check-the-box regulations might argue that the Court should overrule its holding in Morrissey. This is a difficult argument to win, given the Court's well-established reluctance to overruling its statutory interpretation precedents. ${ }^{282}$

In discussing the merits of this strategy, it should first be noted that the context for this argument (i.e., that the Court should overrule its own statutory interpretation precedent) would be quite unusual. A party generally makes this argument by requesting that the Court strike down the old interpretation and adopt a new, alternative judicial interpretation. ${ }^{283}$ In this case, however, a proponent of the check-the-box regulations would be arguing for the Court merely to strike down the old precedent; the proponent would not ask the Court to adopt a new judicial interpretation. Rather, the proponent would ask the Court to leave the Treasury space to operate. ${ }^{284}$ In other words, the proponent

278 See supra Part III.A (discussing whether the check-the-box regulations would be upheld under a Chevron analysis).

279 United States v. Mead Corp., 533 U.S. 218, 248 (2001) (Scalia, J., dissenting).

280 Id. at 248-49.

281 Merrill, supra note 16, at 989.

282 See, e.g., Neal v. United States, 516 U.S. 284, 295-96 (1996); Ankenbrandt v. Richards, 504 U.S. 689, 699-700 (1992); Hilton v. S.C. Pub. Rys. Comm'n, 502 U.S. 197, 202 (1991); Patterson v. McLean Credit Union, 491 U.S. 164, 172 (1989) (indicating that stare decisis has special force in the statutory interpretation context); see also Eskridge, supra note 89, at 1362-63 (describing the Court's "super-strong presumption of correctness" with regard to its statutory interpretation precedents).

283 See, e.g., Ankenbrandt, 504 U.S. at 699-700; Hilton, 502 U.S. at 202; Patterson, 491 U.S. at 172 (upholding earlier judicial interpretation despite arguments that the Court should adopt a different interpretation).

284 One might wonder whether the proponent could ask the Court to overrule Morrissey and then adopt the check-the-box regulations' definition of association. The regulations' elective regime, however, involves a highly bureaucratic process. For example, the 
would be asking the Court to wipe the slate clean, thereby allowing the Meadqualified check-the-box regulations to stand.

It is unclear whether this different context would make it more or less likely for the Court to take the unusual step of overruling its own precedent. On the one hand, in this context the agency charged with administering the statute has spoken in a formal Mead-qualified manner, concluding that a different interpretation would be best. ${ }^{285}$ Because of this expert opinion, and perhaps in the interest of inter-branch comity, this unusual context might cause the Court to be more receptive than usual to the argument that it should overrule its statutory interpretation precedent.

On the other hand, the Court might be offended by an agency's brazenness in so clearly contradicting an existing Supreme Court precedent directly on point. ${ }^{286}$ In such a case, the Court might desire to send a strong message to the executive branch that such tactics will not result in a successful end run around the general rule that agencies must go to Congress to change settled law. The Court could send such a message by summarily refusing an invitation to reconsider its precedent in this context, thereby forcing the agency to turn to Congress.

In what appears to be the only case in which the issue arose in this context, the Court rejected the argument that it should overrule its prior statutory interpretation precedent. In the Neal case discussed earlier, ${ }^{287}$ the defendant asked the Court to reconsider its precedent holding in Chapman v. United

regulations specify the time, place, and method for filing the classification election with the IRS. See Treas. Reg. $\S 301.7701-3$ (c). Because of this bureaucratic process, it is difficult to see how the Court itself could reinterpret the term association as the regulations do.

${ }^{285}$ See Pierce, supra note 41 , at 2260 (suggesting that in this context, the Court "should use the occasion of the announcement of the agency construction as an indication of the need to reconsider the precedent").

${ }^{286}$ See Chi. \& S. Air Lines, Inc. v. Waterman S.S. Corp., 333 U.S. 103, 113 (1948). The Court maintained:

[I]f the President may completely disregard the judgment of the court, it would be only because it is one the courts were not authorized to render. Judgments within the powers vested in courts by the Judiciary Article of the Constitution may not lawfully be revised, overturned or refused faith and credit by another Department of Government.

Id. Cf. City of Boerne v. Flores, 521 U.S. 507, 536 (1997) ("When the political branches of the Government act against the background of a judicial interpretation of the Constitution already issued, it must be understood that in later cases and controversies the Court will treat its precedents with the respect due them under settled principles, including stare decisis, and contrary expectations must be disappointed.").

287 See supra text accompanying notes 95-99. In the other two cases in the incorporation rule trilogy, the Court, in deciding that the agency action was foreclosed by its precedent holding, did not extensively address the argument that it should overrule the precedent. In Lechmere, Inc. $v$. NLRB, the Court did not address the argument at all. 502 U.S. 527 (1992). In Maislin Indus., U.S., Inc. v. Primary Steel, Inc., the Court very briefly addressed the argument, stating in a conclusory manner that "Congress has not diverged from [the Court's prior] interpretation and we decline to revisit it ourselves." 497 U.S. 116, 131 (1990). 
States $^{288}$ that, in calculating the amount of a "mixture or substance" of LSD for criminal sentencing purposes, the actual weight of blotter paper was to be counted. 289 The defendant, however, did not request that the Court adopt a new judicial interpretation; rather the defendant asked the Court to defer to the position of the United States Sentencing Commission that every dose of LSD on any carrier medium would automatically be given a presumed weight of 0.4 milligrams. ${ }^{290}$ The Court quickly disposed of the defendant's request that the Court overrule its precedent:

Our reluctance to overturn precedents derives in part from institutional concerns about the relationship of the Judiciary to Congress. One reason that we give great weight to stare decisis in the area of statutory construction is that "Congress is free to change this Court's interpretation of its legislation." We have overruled our precedents when the intervening development of the law has "removed or weakened the conceptual underpinnings from the prior decision, or where the later law has rendered the decision irreconcilable with competing legal doctrines or policies." Absent those changes or compelling evidence bearing on Congress' original intent, our system demands that we adhere to our prior interpretations of statutes. Entrusted within its sphere to make policy judgments, the Commission may abandon its old methods in favor of what it has deemed a more desirable "approach" to calculating LSD quantities. We, however, do not have the same latitude to forsake prior interpretations of a statute. True, there may be little in logic to defend the statute's treatment of LSD; it results in significant disparity of punishment meted out to LSD offenders relative to other narcotics traffickers. ... Even so, Congress, not this Court, has the responsibility for revising its statutes. Were we to alter our statutory interpretations from case to case, Congress would have less reason to exercise its responsibility to correct statutes that are thought to be unwise or unfair. ${ }^{291}$

The Neal Court, while acknowledging that Chapman was probably unwise from a policy perspective, refused to reconsider the decision in the absence of either (1) an intervening development in the law that had "removed or weakened [the prior decision's] conceptual underpinnings" or "rendered [it] irreconcilable with competing legal doctrines or policies" or (2) the emergence of "compelling evidence bearing on Congress' original intent."292 Neal also explained that the basis for the Court's reluctance to overrule its statutory precedents is the recognition that Congress is free to change any interpretation

288500 U.S. 453, 455 (1991).

289 Neal v. United States, 516 U.S. 284, 295-96 (1996).

290 Id. at 289.

291 Id. at 295-96 (citations omitted).

292 Id. at 295 (internal quotations omitted). 
of which it does not approve. ${ }^{293}$ In addition, the Neal Court was concerned that frequent reconsideration of statutory precedents would reduce the incentive for Congress to amend statutes that it considers unsatisfactory. ${ }^{294}$

A similar analysis of the Morrissey decision leads to the conclusion that it, like Chapman, should not be overruled. Since there has been no new evidence bearing on Congress's original intent with regard to its use of the term "association," the only remaining issue under Neal is whether there has been an "intervening development of the law, through either the growth of judicial doctrine or further action taken by Congress," 295 that might affect the continuing vitality of Morrissey.

Intervening developments in law actually support, rather than undermine, the vitality of Morrissey. In 1987, over fifty years after Morrissey, Congress enacted $\S 7704$ against the classification backdrop created by the Morrissey Court. ${ }^{296}$ This enactment, the most recent legislative action in the classification area, by its text governs only partnerships, which were then defined through the application of the corporate resemblance test. ${ }^{297}$ Thus, Morrissey is the foundation on which $\S 7704$ was built, and as a result, the enactment of this section indicates congressional approval of the corporate resemblance test. ${ }^{298}$

Therefore, it seems that intervening developments in law (i.e., the enactment of $\S 7704$ ) actually serve to ratify the corporate resemblance test created by Morrissey. A proponent of the check-the-box regulations might argue, however, that intervening developments in state law since the enactment of $\S 7704$, namely the advent of the LLC, undermine the vitality of Morrissey. According to this argument, the popularity of the LLC essentially made Morrissey obsolete, since non-publicly traded entities could manipulate the four factors to their satisfaction. This, however, is not a change in the law that weakens Morrissey's conceptual underpinnings. Rather, the proliferation of LLCs, like the proliferation of publicly traded partnerships that triggered the enactment of $\S 7704$, is a change in facts, and a change in facts is insufficient

293 Id.

$294 \mathrm{Id}$. at 296.

295 Patterson v. McLean Credit Union, 491 U.S. 164, 173 (1989).

296 See supra text accompanying notes 206-207.

297 Id.

298 The building block nature of Morrissey with regard to $\$ 7704$ is confirmed by $\S 7704$ 's legislative history. This legislative history extensively discusses the corporate resemblance test created by Morrissey. See authorities cited supra note 210. Section 7704 supports the vitality of Morrissey in another way. In enacting $\$ 7704$, Congress drastically altered the classification landscape by taxing publicly traded partnerships as per se corporations for the first time. See supra text accompanying notes 200-205. In making such a drastic change, however, Congress did not see fit to repeal the corporate resemblance test. In leaving the corporate resemblance definition of "association" untouched in the process of substantially altering the law of the tax classification of business entities, Congress appeared to ratify the corporate resemblance test. 
to support a Court overruling its prior statutory interpretation. ${ }^{299}$ Congress is charged with the responsibility of adapting settled law to new facts. Overruling Morrissey would give Congress "less reason to exercise [this] responsibility." 300

In summary, it is unlikely that the Court would overrule its interpretation in Morrissey in order to validate the check-the-box regulations because Congress, through subsequent legislative enactment of $\S 7704$, appeared to ratify the holding of Morrissey. As a result, the Court would likely conclude that only Congress could dispose of the corporate resemblance test. ${ }^{301}$

\section{e. Ratification of the Regulations by Acquiescence}

Because it has been over six years since the check-the-box regulations became effective, one might argue that congressional inaction in the classification area since that time indicates approval of the elective regime. Under this view, congressional inaction indicates tacit acquiescence to the new regime.

Scholars have generally been very skeptical of drawing inferences from congressional inaction. ${ }^{302}$ As a result, this argument could be attacked from that perspective. These arguments, however, are unnecessary because the argument that congressional inaction ratifies the regulations by acquiescence should fail on much simpler grounds.

First, the doctrine of legislative acquiescence is used by courts to uphold one arguably plausible agency interpretation of an ambiguous statute instead of adopting a different, arguably more plausible judicial interpretation. ${ }^{303}$ It cannot be used to uphold an agency interpretation that the statute simply will not bear. ${ }^{304}$ Therefore, the doctrine of acquiescence does not allow Congress

299 See Patterson v. McLean Credit Union, 491 U.S. 164, 173 (1989) (stating that "an intervening development of the law," not facts, is a basis for overruling statutory interpretation precedent (emphasis added)). Cf. Planned Parenthood of Southeastern Pa. v. Casey, 505 U.S. 833, 860 (1992) (noting that changed factual circumstances may justify a departure from precedent in the constitutional interpretation context).

300 Neal v. United States, 516 U.S. 284, 296 (1996).

301 See California v. FERC, 495 U.S. 490, 499 (1990) (recognizing the respect the Court "must accord to [its] longstanding and well-entrenched decisions, especially those interpreting statutes that underlie complex regulatory regimes").

302 See, e.g., Eskridge, supra note 89, at 95-108 (questioning the ability to presume intent from the collective inaction of Congress).

${ }^{303}$ See, e.g., Bob Jones Univ. v. United States, 461 U.S. 574, 599-601 (1983) (attributing significance to congressional inaction over the course of twelve years in the face of numerous proposals to overturn an IRS interpretation of a prior statute).

304 See Leary v. United States, 395 U.S. 6, 25 (1969) (concluding that " $[\mathrm{w}]$ hen a regulation conflicts with the statute, the fact of subsequent re-enactment 'is immaterial, for Congress could not add to or expand [the] statute by impliedly approving the regulation"" (second alteration in the original) (quoting Commissioner v. Acker, 361 U.S. 87, 93 (1959))); Louisville \& Nashville R.R. Co. v. United States, 282 U.S. 740, 759 (1931) 
to change the statute by inaction; ${ }^{305}$ rather, it only allows Congress to confirm a plausible interpretation of the statute by inaction.

The incorporation rule treats the Morrissey standard as though it is part of the underlying statute. ${ }^{306}$ Accordingly, using the acquiescence doctrine to uphold a different standard would allow Congress to effectively change the statute through inaction, an impermissible use of the doctrine. ${ }^{307}$

Second, it is unclear to which "law" Congress would be acquiescing. If a legislator reviewed the state of the law immediately after the regulations were issued, the legislator might conclude, as this article does, that the regulations were invalid and that the Morrissey corporate resemblance test still controlled. At the time the regulations were promulgated, the Court had just unanimously confirmed in Neal that its interpretations trump subsequent agency interpretations. ${ }^{308}$ Accordingly, it then appeared that Morrissey remained "good law." Therefore, if this legislator did nothing, one might conclude that the legislator approved of this good law, not the invalid elective regime. This second problem is related to the first problem because, in the usual case, the upheld interpretation (i.e., a plausible interpretation) is not patently unlawful. ${ }^{309}$

("Long continued practice and the approval of administrative authorities may be persuasive in the interpretation of doubtful provisions of a statute, but cannot alter provisions that are clear and explicit ....").

305 See Leary, 395 U.S. at 25 (concluding that Congress cannot change a statute through inaction, by "impliedly approving" a regulation which contradicts the statute).

306 See supra Part III.B.1.

307 See Biddle v. Comm'r, 302 U.S. 573, 582 (1938) ("Where the law is plain the subsequent re-enactment of a statute does not constitute adoption of its administrative construction.").

308 See Neal v. United States, 516 U.S. 284, 295 (Jan. 22, 1996) ("Once we have determined a statute's meaning, we adhere to our ruling under the doctrine of stare decisis, and we assess an agency's later interpretation of the statute against that settled law."); 61 Fed. Reg. 66,584 (Dec. 18, 1996) (to be codified at 26 C.F.R. pts. 1, 301, 602) (finalizing the check-the-box regulations).

${ }^{309}$ In the usual case in which the acquiescence doctrine is applied, the Court is considering whether to change one plausible interpretation of a statute by an agency to another. See supra text accompanying note 303 . In this context, a legislator reviewing the statute after the initial interpretation might do nothing if he was satisfied with the interpretation, believing that legislation was unnecessary because the issue had already been settled. Accordingly, one could surmise from inaction that the legislator approved of the initial interpretation. If, however, the initial interpretation was clearly invalid (because, for example, it was incompatible with the statutory text), the implications of the inaction of a legislator depend on the legislator's knowledge that the interpretation was invalid. If the legislator knew the interpretation was invalid, he might do nothing if he disapproved of it, knowing that a court would ultimately strike it down. If the legislator mistakenly thought the interpretation was valid, he might do nothing if he approved of it, thinking that the interpretation was now settled. 


\section{How COUld TREASURy HaVe IsSUEd INVAlid REGUlations?}

This Part considers how the Treasury could have promulgated the checkthe-box regulations despite their invalidity in light of Morrissey. This action by the Treasury is somewhat remarkable in two respects. First, the regulations deal with an important and pervasive area of tax law that affects the classification of almost every unincorporated business entity. ${ }^{310}$ The regulations do not cover some arcane, technical area of tax law that affects only a few taxpayers, where such an error might be understandable. Second, the validity of the regulations was specifically highlighted as an issue when an elective regime was first raised, and many distinguished commentators, including the Joint Committee on Taxation ${ }^{311}$ and the New York State Bar Association Tax Section, ${ }^{312}$ specifically addressed the issue, but failed to discuss the incorporation rule.

There are two possible explanations for the Treasury's action, although an accurate explanation probably involves some combination of the two. These possible explanations are discussed below.

\section{A. Negligence and the Sociology of the Tax Community}

One explanation could be pure ignorance of the incorporation rule on the part of the tax community, which tends to have an unduly myopic vision of the law. ${ }^{313}$ Professor Coverdale used this theory to explain why courts reviewing tax regulations were so inconsistent in citing Chevron and using its two step methodology, emphasizing the isolation of the highly specialized tax bar and bench. ${ }^{314}$

Under this theory, the tax experts at the Treasury, IRS, and Joint Committee on Taxation erroneously applied administrative law doctrine, jumping directly to the question of whether the regulations would be upheld under Chevron without adequately considering the impact of Morrissey. Likewise, under this view, the private tax practitioners who specifically commented on the regulations' validity merely got the administrative law wrong.

\section{B. Intent and the Effect of Taxpayer Standing Doctrine}

A more cynical explanation is that the Treasury was aware of the regulations' invalidity yet issued them anyway because it severely discounted

310 See supra text accompanying notes 220-221.

311 See JCT REPORT, supra note 12, at 13-17.

312 See NY State Bar Report, supra note 223.

313 See Paul L. Caron, Tax Myopia, or Mamas Don't Let Your Babies Grow Up To Be Tax Lawyers, 13 VA. TAX REV. 517, 518 (1994) (observing that "tax law too often is mistakenly viewed by lawyers, judges, and law professors as a self-contained body of law").

314 Coverdale, supra note 129, at 53-54 n.121 (hypothesizing that the "highly specialized" nature of tax law leaves tax lawyers and judges either unaware of Chevron or under the impression "that other doctrines are controlling in tax"); see also supra text accompanying notes $136-144$. 
the likelihood of any judicial challenge. Under this view, the Treasury intentionally promulgated invalid regulations but determined that the regulations were insulated from a challenge due the very restrictive taxpayer standing doctrine discussed below. If, however, the Treasury had this troubling view, it was short-sighted because, although a taxpayer with standing to challenge the regulations might be hard to find, it is inevitable that such taxpayers exist.

In general, taxpayers do not have standing in a suit that concerns someone else's taxes because the relief sought would not benefit the taxpayer in any tangible way. ${ }^{315}$ In other words, a person does not have standing to challenge a tax rule merely because of one's status as a taxpayer; rather, the person must suffer a tangible injury in order to challenge the validity of a regulation.

Applying this taxpayer standing doctrine to the check-the-box regulations, a taxpayer challenging the validity of the regulations would have to show that his tax liability is higher under the regulations than under Morrissey's corporate resemblance test. Because the check-the-box regulations allow an entity to elect its classification, it might appear on first glance that all taxpayers in all instances will fare no worse under the regulations than under Morrissey. If this were the case, no one would have standing to challenge the regulations. Although these regulations will generally work to the taxpayer's benefit (or at least not to the taxpayer's detriment), there will be certain situations where the taxpayer would be better off under the corporate resemblance test. 316 One could think of a number of such scenarios; three examples are provided below.

\section{The Case of the Foreign Entity's Failure to Elect}

Under the check-the-box regulations, eligible entities elect whether to be classified as a corporation or a partnership by filing Form 8832 with the IRS. ${ }^{317}$ The regulations contain default rules that classify unincorporated entities in the absence of an affirmative election. ${ }^{318}$ The default rules classify all domestic entities as partnerships, ${ }^{319}$ classify foreign entities that do not provide limited liability for all of their owners as partnerships, ${ }^{320}$ and classify

315 See Massachusetts v. Mellon, 262 U.S. 447, 487 (1923) (explaining that any statute that produces additional taxes is "a matter of public and not of individual concern"); see also Simon v. E. Ky. Welfare Rights Org., 426 U.S. 26, 46 (1976) (Stewart, J., concurring) ("I cannot now imagine a case, at least outside the First Amendment area, where a person whose own tax liability was not affected ever could have standing to litigate the federal tax liability of someone else."); BoRIS I. BITTKER ET AL., FEDERAL INCOME TAXATION OF INDIVIDUALS If 51.10[4], at 51-58 to $51-60$ (3d ed. 2002) (discussing standing barriers to suits brought by plaintiffs concerning someone else's taxes).

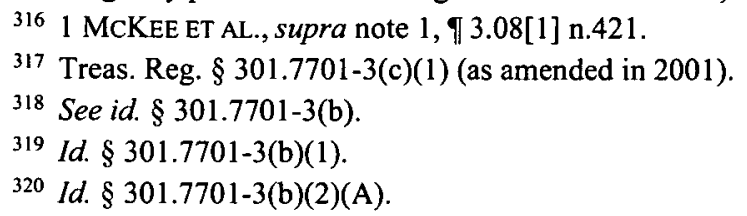


foreign entities that do provide limited liability for all of their owners as corporations. ${ }^{321}$

Because partnership classification is generally desirable due to flow-through taxation, ${ }^{322}$ the default rules that classify entities as partnerships are taxpayerfavorable. Under these default rules, no entity will receive the generally less desirable corporate classification unless it affirmatively elects otherwise. ${ }^{323}$

With regard to foreign entities that provide limited liability for all of their owners, however, the default rules are unfavorable. These entities will receive the generally less desirable corporate classification if they fail to make an affirmative election. ${ }^{324}$

Accordingly, if one of these entities accidentally failed to elect partnership status, it would have standing to challenge the regulations' validity if the corporate resemblance test would have classified the entity as a partnership. For example, assume that a foreign entity that provides all of its owners with limited liability accidentally fails to elect partnership status. If the entity lacks two of the remaining three corporate characteristics of perpetual existence, free transferability of interests, and centralized management, the entity would have been classified as a partnership under the corporate resemblance test. ${ }^{325}$ However, because the entity failed to make an affirmative election under the check-the-box regulations, it is taxed as a corporation. ${ }^{326}$ In an attempt to avoid the corporate tax on its income, the entity would have standing to challenge the validity of the check-the-box regulations.

\section{The Case of the Partner Trying to Avoid an Allocation of Ordinary Income}

If the IRS asserts a deficiency arising out of an allocation of income from a partnership (as classified under the check-the-box regulations), the taxpayer could avoid that allocation by showing that the partnership was really a corporation, as corporate income does not flow through to its shareholders. ${ }^{327}$ Thus, if the allocation came from an LLC that had all four corporate characteristics, the taxpayer could attempt to avoid the allocation by arguing that the check-the-box regulations were invalid. If the argument succeeds, the LLC would be classified as a corporation under the corporate resemblance test. ${ }^{328}$

Although this may be a successful strategy to avoid an allocation, the

321 Id. $\S 301.7701-3(\mathrm{~b})(2)(\mathrm{B})$.

322 See MuNDSTOCK, supra note 213, at 10.

323 See Treas. Reg. $\$ 301.7701-3(b)(1)$.

324 See id. $\$ 301.7701-3(\mathrm{~b})(2)(\mathrm{B})$.

325 See supra text accompanying notes 191-194.

326 See Treas. Reg. § 301.7701-3(b)(2)(B).

327 Cf. I.R.C. $\S 702$ (a) (requiring a partner to include his or her distributive share of the partnership's income in his or her gross income).

328 See supra text accompanying notes 191-194. 
taxpayer would have to take into account collateral issues before undertaking this strategy. For example, the LLC would now be considered a corporation, and thus all of its income would be subject to the double tax regime..$^{329}$ Furthermore, if the taxpayer had previously received the benefit of flowthrough losses, they would now be lost. ${ }^{330}$ In fact, even if the flow-through losses involved taxable years for which the statute of limitations had run, the IRS might be able to reverse the taxpayer's tax benefits resulting from those losses under "the uncertain and confusing judicial doctrines of equitable estoppel and recoupment" 331 because of the taxpayer's inconsistent positions taken with regard to the LLC's classification (first as a partnership, then as a corporation). In short, arguing that the regulations are invalid in order to avoid an allocation of income would not be wise in most cases because the taxpayer would essentially win the battle (by avoiding the allocation of income) but lose the war (by implicating these collateral concerns).

One could, however, envision a scenario where these collateral concerns are absent or minimal. For example, assume that on January 1, 2000, Taxpayer acquires a $50 \%$ membership interest in an LLC, a partnership under the checkthe-box regulations but a corporation under the corporate resemblance test. Taxpayer acquires his interest for $\$ 1,000,000$. In 2000 , the LLC earns $\$ 10,000,000$ of income and reinvests the income, rather than distributing it. On January 2, 2001, Taxpayer sells his $50 \%$ interest to a third party for $\$ 6,000,000$.

Under the check-the-box regulations, Taxpayer would have ordinary income (taxed at a maximum rate of $35 \%{ }^{332}$ ) on the $\$ 5,000,000$ allocation of ordinary income to him from the partnership. ${ }^{333}$ Because Taxpayer's basis in his partnership interest would be adjusted to reflect this allocation, ${ }^{334}$ no additional tax would be due in 2001 when he sells his interest. ${ }^{335}$

329 See supra text accompanying notes 147-150 (explaining how corporation income is generally taxed twice, once at the corporate level and once at the shareholder level).

${ }^{330} \mathrm{Cf}$. I.R.C. $\S 702$ (a) (allowing a partner to include his or her distributive share of the partnership's losses on his or her individual income tax return).

331 BITTKER ET AL., supra note 315, 149.10 , at 49-27.

332 See I.R.C. $\S 1$ (a)-(d) (setting tax rates for individuals).

333 See I.R.C. $\$ \S 702(a), 704$ (a) (requiring partners to include distributive share of partnership income in gross income and providing that in general partner's distributive share shall be determined by the agreement of the partners).

334 See I.R.C. $\S 705(\mathrm{a})(1)(\mathrm{A})$ (providing that partner's basis in partnership interest is adjusted upwards to reflect partner's distributive share of partnership income).

335 Taxpayer's initial basis in his partnership interest is its cost of $\$ 1,000,000$. See I.R.C. $\S 1012$ (explaining that the basis of property is the cost of that property). Section 705(a) requires that this basis is adjusted upward to reflect the $\$ 5,000,000$ of income allocated to Taxpayer. Accordingly, at the time of sale, Taxpayer's basis is $\$ 6,000,000$. Consequently, when Taxpayer sells the interest for $\$ 6,000,000$, he has no gain or loss. See I.R.C. $\S 1001$ (a) (computing gain or loss on sale as the difference between the amount realized and basis); $i d$. $\S 1001$ (b) (defining amount realized as amount of money plus the fair market value of 
However, under Morrissey, Taxpayer would have no tax liability in 2000 because the LLC would be classified as a corporation. ${ }^{336}$ In 2001, when Taxpayer sells his "stock," he would recognize a long-term capital gain (taxed at a maximum rate of $15 \%$ ) of $\$ 5,000,000.337$ Therefore, by arguing that the check-the-box regulations are invalid, Taxpayer could save up to $\$ 1,000,000$ by effectively converting ordinary income into a long-term capital gain. ${ }^{338}$

\section{The Case of the Corporate Purchaser Attempting to Preserve Losses}

The last example involves a corporate purchaser of an LLC, which is classified as a partnership under the check-the-box regulations but would have been classified as a corporation under the corporate resemblance test, that had incurred significant losses prior to the purchase. Under a partnership classification, the LLC's losses would have flowed through to the prior owners to be reported on their prior returns. ${ }^{339}$ Alternatively, under a corporate classification, the losses would be carried forward by the LLC for future use. ${ }^{340}$ Therefore, the purchaser might argue that the check-the-box regulations were invalid in order to preserve these losses for future use.

Under this argument, the LLC would be considered a wholly owned subsidiary of the corporate purchaser; as a result, the corporate purchaser would either be able to consolidate its tax returns with the $L_{L C} C^{341}$ or be

property received).

${ }^{336}$ Cf. I.R.C. $\& 702$ (a) (requiring partner to include distributive share of partnership income in gross income).

337 See I.R.C. $\S 1001$ (a) (computing gain or loss on sale as the difference between the amount realized and basis); $i d$. $\S 1001$ (b) (defining amount realized as amount of money plus the fair market value of property received). Taxpayer's basis in the stock is $\$ 1,000,000$. See I.R.C. $\S 1012$ (explaining that the basis of property is the cost of that property). His amount realized on the sale is $\$ 6,000,000$. See I.R.C. $\$ 1001$ (b) (defining amount realized as amount of money plus the fair market value of property received). As a result, he has a $\$ 5,000,000$ gain on the sale. See I.R.C. $\$ 1001$ (a) (computing gain or loss on sale as the difference between the amount realized and basis). Since the stock is a capital asset, see I.R.C. $\S 1221$ (a), that has been held for more than a year, the gain is classified as a long-term capital gain. See I.R.C. § 1222(3) (defining "long-term capital gain" as a "gain from the sale or exchange of a capital asset held for more than 1 year"). Therefore, the gain is taxed at a maximum rate of $15 \%$. See I.R.C. $\S 1(\mathrm{~h})$ (setting maximum capital gain rates).

338 Assuming that all income is taxed at the maximum rate, Taxpayer would owe tax of $\$ 1,750,000(35 \%$ of $\$ 5,000,000)$ if the LLC is considered a partnership and tax of $\$ 750,000$ $(15 \%$ of $\$ 5,000,000)$ if the LLC is considered a corporation.

${ }^{339}$ See I.R.C. $\S 702(a)$ (requiring partners to include their distributive shares of partnership losses on their individual tax returns); I.R.C. $\S 703(\mathrm{a})(2)(\mathrm{D})$ (precluding a partnership from taking deductions for net operating losses).

${ }^{340}$ See I.R.C. $\$ 172$ (a) (allowing a deduction for net operating losses).

341 See I.R.C. $\$ 1501$ (allowing an "affiliated group of corporations" to file consolidated returns); I.R.C. $\S 1504$ (a) (defining the term "affiliated group of corporations" to include a parent and a wholly owned subsidiary). 
eligible for the dividends-received deduction with regard to distributions from the LLC. ${ }^{342}$ Therefore, the corporate purchaser will suffer no adverse consequences from reclassifying the LLC as a corporation by arguing that the check-the-box regulations are invalid.

In summary, one can conceive of many situations in which a taxpayer would benefit from transmuting his partnership interest into an interest in a corporation by arguing that the check-the-box regulations are invalid. Therefore, if the Treasury knowingly promulgated these invalid regulations because it determined that no one would ever have standing to challenge the regulations, it was mistaken. It would appear to be only a matter of time before the right taxpayer with the right facts will challenge the validity of the regulations. ${ }^{343}$

Finding the true explanation for the Treasury's decision to promulgate these invalid regulations involves some speculation. The explanation probably lies somewhere between the two extremes. The Treasury might have believed that the regulations were at least arguably valid, while recognizing that a court would strive hard to find them valid. Furthermore, the Treasury was possibly comforted by the mistaken belief that no taxpayer would ever have standing to challenge the regulations.

\section{TREASURY'S TREND}

When faced with a Supreme Court interpretation of an ambiguous statutory term in the Code that it wants changed, the Treasury has three options. First, it could propose legislation to Congress to amend the underlying statute. Second, it could promulgate regulations that purport to change the interpretation in a taxpayer-adverse manner. Third, it could promulgate regulations that purport to change the interpretation in a taxpayer-friendly manner. This article has shown that only the first solution-go to Congress-is valid. $^{344}$ Despite this reality, however, the Treasury has shown a recent tendency to choose the third solution-attempting to change the interpretation in a taxpayer-friendly manner.

The check-the-box regulations, the subject of this article, represent one example of this trend. Another example is the Treasury's recent promulgation of regulations regarding the important issue of whether an expense can be immediately deducted or must be capitalized. ${ }^{345}$ Like the check-the-box regulations, these regulations are generally taxpayer-friendly ${ }^{346}$ (although not

342 See I.R.C. $\S 243(a)$, (b) (allowing a parent of a wholly owned subsidiary a $100 \%$ dividends received deduction with respect to dividend distributions from subsidiary to parent).

343 See 1 MCKEE ET AL., supra note 1, at \ 3.08 n.421.

344 See supra Part I.D.

345 See Guidance Regarding Deduction and Capitalization of Expenditures, 69 Fed. Reg. 436 (Jan. 5, 2004) (to be codified at 26 C.F.R. pt. 1).

${ }^{346}$ See Calvin H. Johnson, Destroying Tax Base: The Proposed INDOPCO 
in every single case ${ }^{347}$ ) and have been extensively praised by private practitioners. ${ }^{348}$ Like the check-the-box regulations, these regulations are also inconsistent with a Supreme Court decision, INDOPCO v. Commissioner, ${ }^{349}$ that is directly on point. ${ }^{350}$ Accordingly, these regulations are invalid to the extent they are inconsistent with INDOPCO.

Yet another example involves the tax treatment of expenses for auditing and training sessions paid by members of the Church of Scientology. In 1993, the IRS issued Revenue Ruling 93-73, which allowed Church of Scientology members to deduct these expenses as charitable contributions. ${ }^{351}$ Like the check-the-box regulations, this Revenue Ruling was taxpayer-friendly because the ruling allowed deductions for expenses that were otherwise nondeductible. ${ }^{352}$ The ruling is also, like the check-the-box regulations, inconsistent with a Supreme Court decision, Hernandez v. Commissioner, that is directly on point. ${ }^{353}$ As a result, this Revenue Ruling is invalid.

Capitalization Regulations, 99 TAX NOTES 1381, 1382 (June 2, 2003), available at LEXIS 99 TN 1381 (explaining that the regulations make it easier for a taxpayer to deduct a cost instead of capitalizing it).

${ }^{347}$ In general, time value of money principles dictate that, all else being equal, the taxpayer prefers an earlier deduction to a later deduction. See generally Lawrence Lokken, The Time Value of Money Rules, 42 TAX L. REV. 1, 20 (1986). Consequently, the regulations are generally taxpayer-friendly in that they make it easier for a taxpayer to deduct rather than capitalize a cost. See Johnson, supra note 346, at 1382 (stating that the regulations allow taxpayers to deduct costs that would otherwise need to be capitalized). In certain instances, however, a taxpayer might prefer to delay a deduction, notwithstanding time value of money concerns. For instance, if the taxpayer will in the future be in a higher tax rate bracket, delaying a deduction until such future time will be beneficial to the taxpayer if the benefit of the tax rate differential exceeds the time value of money cost of delaying the deduction. In such a case, the regulations would be taxpayer-adverse.

348 See, e.g., N.Y. State Bar Ass'n Tax Section, Report on Notice of Proposed Rulemaking on Deduction \& Capitalization of Expenditures Relating to Intangibles, TAX NOTES TODAY, Mar. 26, 2003, available at LEXIS 2003 TNT 58-18; see also Cheyañna L. Jaffke, Sleeping with the Enemy? The IRS'Advanced Notice of Rulemaking Regarding Capitalization, 32 BALTIMORE L. REV. 51, 64 (2002) (describing "the widespread support for the regulation" among taxpayers).

349503 U.S. 79 (1992).

350 See Johnson, supra note 346, at 1386 (stating that the regulations are inconsistent with $I N D O P C O$ ).

351 See also Sklar v. Comm'r, 282 F.3d 610, 614 (9th Cir. 2002) (discussing the IRS's private agreement with the Church of Scientology to allow these deductions, which resulted in the issuance of Rev. Rul. 93-73).

352 Rev. Rul. 93-73, 1993-2 C.B. 75. Unlike the check-the-box regulations and the capitalization regulations, it is likely that no taxpayer may possibly have standing to challenge Revenue Ruling 93-73 except perhaps on First Amendment grounds. See BITTKER ET AL., supra note $315, \S 49.10$ (suggesting that "it is highly unlikely ... that anyone would have standing to challenge [the ruling]").

353490 U.S 680, 690-91 (1989) (concluding that Church of Scientology members may 
It is likely that the restrictive taxpayer standing doctrine plays a role in the Treasury's issuance of these invalid rules. It is not unreasonable to assume that if the Treasury chose to fix problematic Supreme Court interpretations by issuing rules that were taxpayer-adverse, taxpayers would be rushing to the courthouse to challenge the validity of these rules. For instance, if instead of issuing the check-the-box regulations, the Treasury had attempted to cure the quagmire created by the corporate resemblance test by issuing a regulation that made limited liability the sole criterion for association status, many challenges would quickly have ensued.

What does all of this mean for the Treasury? With regard to the check-thebox regulations, the Treasury should propose "check-the-box" legislation to Congress or legislation that would specifically authorize the Treasury to create an elective classification regime. Likewise, the Treasury should withdraw the invalid capitalization regulations and seek legislative action instead.

More generally, the Treasury should recognize that Supreme Court interpretations are binding on the executive branch and that any change to such an interpretation always, without exception, requires legislative action. Furthermore, the Treasury should appreciate that, although it might be difficult to find taxpayers who have standing to challenge taxpayer-friendly rules, it is almost inevitable that they do exist.

\section{CONCLUSION}

After approximately eighty years of seemingly endless classification battles with taxpayers, the Treasury finally capitulated by promulgating the check-thebox regulations. These fundamental regulations, which have been extensively praised by taxpayers, allow nonpublicly traded, unincorporated business entities to elect their classification for tax purposes. As a result, the regulations appear to relegate the Morrissey corporate resemblance standard to a historical footnote. Unfortunately, while discarding this standard may well represent a wise policy choice, the choice was not the Treasury's to make.

Had the regulations been issued on a clean slate, it is arguable that they would have satisfied the deferential Chevron two step test and been upheld. Nonetheless, the trilogy of Supreme Court cases underlying the incorporation rule makes clear that the executive branch cannot simply discard a Supreme Court interpretation of an ambiguous statutory term and insert a Meadqualified interpretation in its stead. Rather, the executive branch is inexorably bound by the Court's interpretation until Congress amends the underlying

not deduct expenses for auditing and training sessions); see also Douglas A. Kahn \& Jeffrey H. Kahn, "Gifts, Gafts and Gefts"-The Income Tax Definition and Treatment of Private and Charitable "Gifts" and a Principled Policy Justification for the Exclusion of Gifts from Income, 78 NOTRE DAME L. REv. 441, 506-509 (discussing Hernandez and Rev. Rul. 93-73 and maintaining that the "current tax law is in the awkward posture of the Service having effectively repudiated its own victory in obtaining a Supreme Court ruling and instead allowing deductions for what the Supreme Court held to be [non-deductible]"). 
statute or the Court takes the highly unusual step of overruling its statutory interpretation precedent. Since Congress has not amended the underlying statute, and because it is unlikely that the Court would overrule Morrissey in light of Congress's ratification of the decision through its enactment of $\S 7704$, the Treasury's promulgation of the check-the-box regulations was unlawful.

These invalid regulations are but one example of the Treasury's recent trend of overlooking Supreme Court decisions directly on point in the process of issuing taxpayer-friendly rules. The impetus behind this trend likely involves a potent combination of the Treasury's ignorance of administrative law principles and the restrictive taxpayer standing doctrine governing taxpayer lawsuits. Despite the restrictive standing doctrine, it is inevitable that there exist taxpayers who will have both standing to challenge these rules and a significant financial incentive to make such a challenge. Upon such a challenge, these rules, which have been commonly assumed by scholars, practitioners, and commentators to be valid, will likely be declared invalid. 